\title{
التصحر النفسي والاجتماعي لاى الشباب السيناوى \\ بمحافظة شمال سيناء
}
الخولى سالم إبراهيم(1) ، حسن جلال شعبان (2)
(1) رئيس قسم الاجتماع الريفى - كلية الزراعة - جامعة الازهر

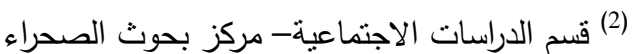

Received: Mar. 6, 2017

Accepted: Apr. 8, 2017

المستخلص : (ل)

يعبش الشباب السيناوى حالة من حالات التصدر النفسى والاجتماعى تتفاوت فى حتتها بين الأولية والبسبطة والثديده

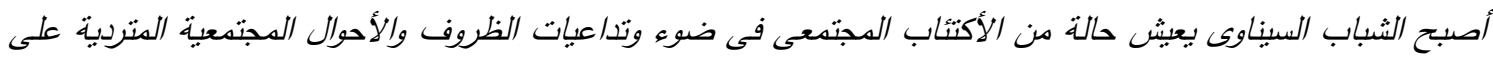
كل المستويات داخل المجتمع السيناوى ولما يحدث على كافة الأصعدة والمستويات من إهدار لأبسط حقوق وكرامة الإنسان

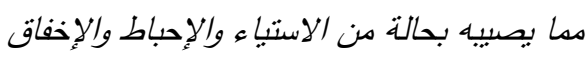

من أهم النتائج التى توصل إلبها البحث فى ضؤ التساؤلات الأساسية وفى حدود الأهداف الخاصة به والاساليب البحثية

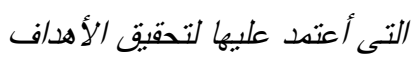

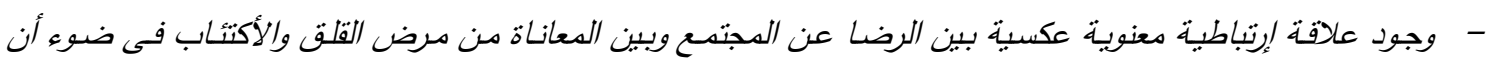

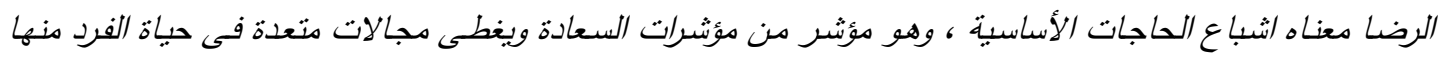

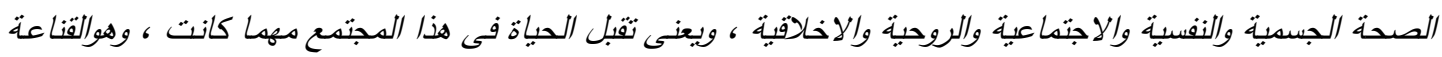

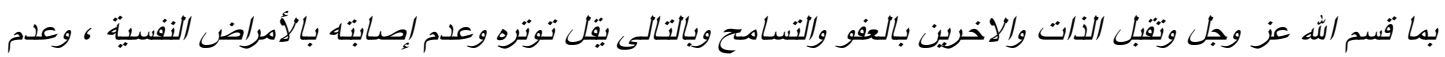
القناعة تجعله قلق ومتوتر وخائف من المستقبل فتجعل حاضره محبط بلا عمل ومستقبل لا بعلده إلا اله .

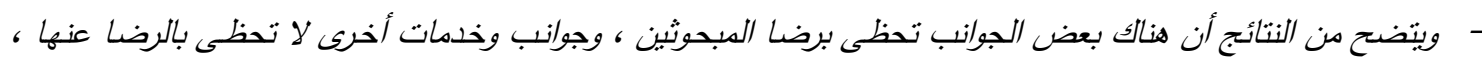

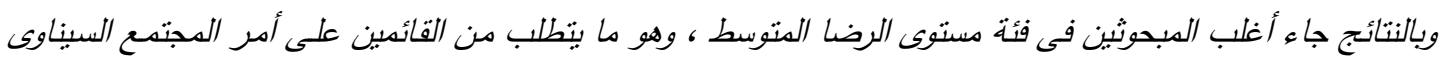
تلبية المطالب وإسنكمال الخدمات من أجل زيادة مستوى رضاهم النفسى واستقرارهم فى الدجتمع .

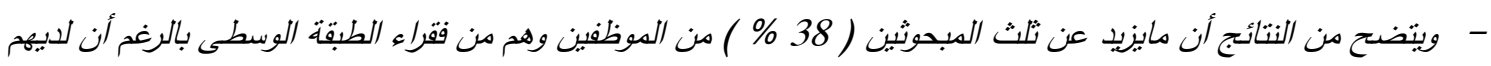

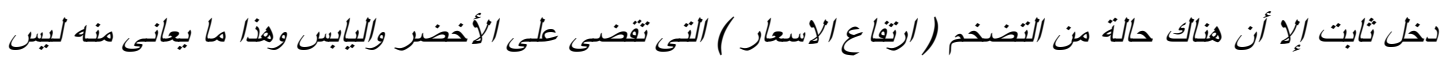

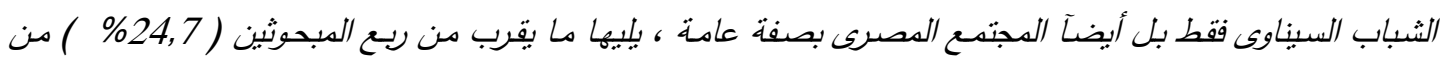

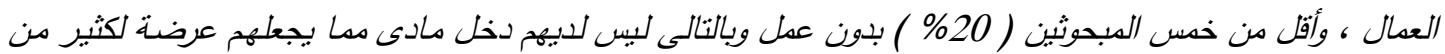
عدم التوافق النفسى والاجتماعى كما أن الشطر الأعظم من كتلة البطالة بتثثل فى بطالة الثباب وتدهور الاوضاع

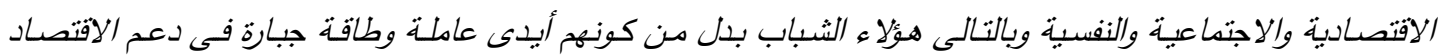

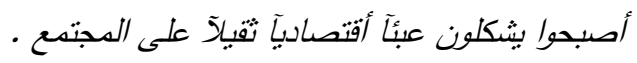
- - ويتضح من النتائج أن صفة الإيمان وما يتبعها من صفات نابعة منها مثل الصدق والأمانة والعدل هى صفات التهات أخلاقية متأصلة لدى الثباب السيناوى . - كما أسفر البحث أن هناك مجموعة من ضنوط الحباة اليومبية كانت من الاسباب الرئيسية فى التصحر النفسى

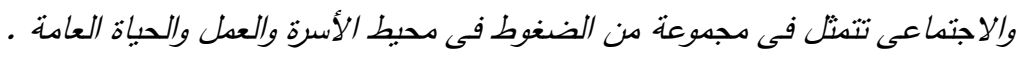
الكلمات المفتاحية : التصحر النفسى والاجتماعى - الشباب - سبناء 
يشبه الحق تبارك وتعالى قسوة قلوبهم فيقول ( فهى

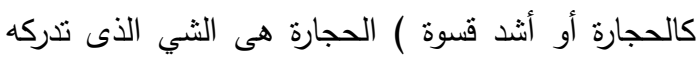

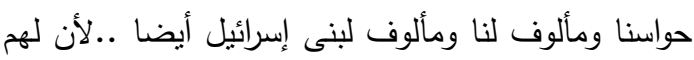

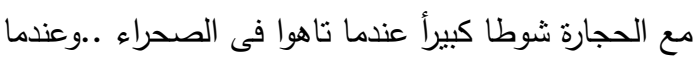
عطشوا وكان سيدنا موسى يضرب لهم الحجر بعصاه . الله تبارك وتعالى لفتهم إلى أن المفروض أن نكون

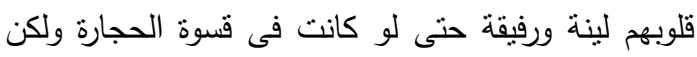

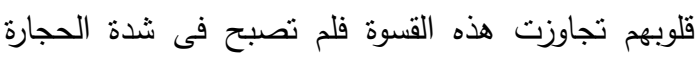
وقسوتها بل هى أثند.

كيف تكون القلوب أنثد قسوة من الحجارة ..لا نتظر

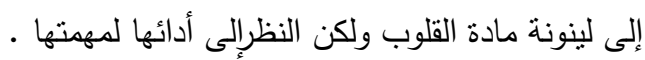
الجبل قسوته مطلوبة لان هذه مهمته أن يكون وتدأ للأرض صلبا قويا ، ولكن هذه القسوة ليست مطلوبة من لهن القلب وليست مهيته ـ أما قلوب بنى إسرائيل فهى أثند

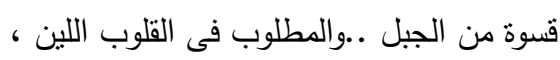
وفى الحجارة القسوة ، فكل صفة مخلوقة لمخلوق ومطلوبة لمهمة . وحين تفسد القلوب وتخرج عن مهونها تكون أفنى من الحجارة..وتكون على العكس من مهيتها.(الشعراوى) وفى مصر، يعيش الإنسان السيناوى حالة من حالات

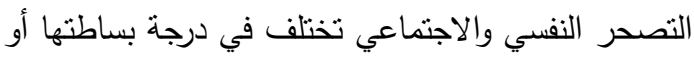

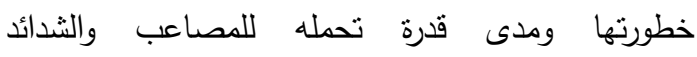
والمتتاقضات والصراعات على المستوى المحلى والإقليمي والعالمي ، فيعاني من التمزق وعدم الرضاء عن النفس والفي والمجتمع وعن الحياة وحالة من التوتر والقلق النفسي والخوف من المستقبل ، فيشعر بالضعف والوهن والانكسار

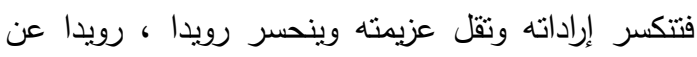

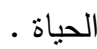

كما أوضحت الأحداث الحالية الدامية المتكررة في

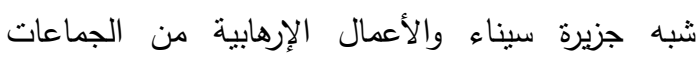
التكفيرية فى الفتزة الأخيرة أن هناك قصورا شديدا ، وإهمالا
المقدمة

قد لا يكون مفهوم التصحر في العلوم الإنسانية

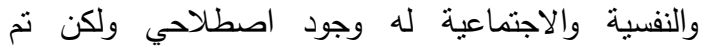
اسنعارته تجاوزاً من العلوم البيئية نظرا لنشوء ظواهر نفسية

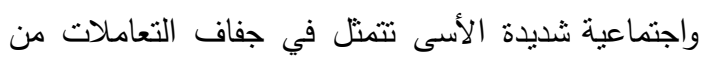
بني البشر، وقد سبق لعلم الاجتماع استعارة مفاهيم من التبل العلوم الأخرى منها على سبيل المثال اصطلاح التوازن

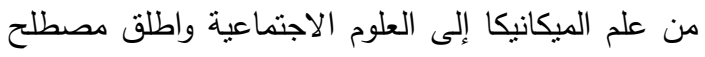

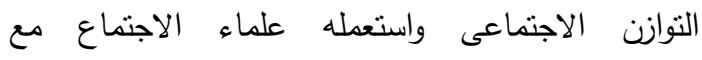

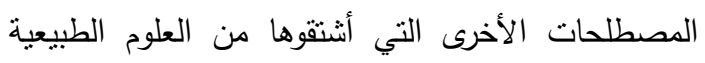
كالتكيف والانسجام والتوافق.

إن تداخل المصطلحات واستعارتها في هذا المضمار

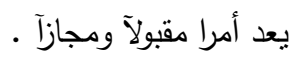

فإذا كان البعض يعتقد أن التصحر يعني بيئة قاحلة

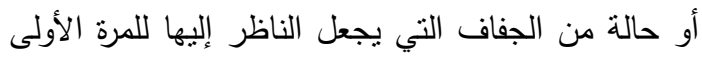
يعتقد استحالة جعلها بيئة منتجة صالحة للعطاء إلا بعد بذل الكم الهائل من الجهود المضنية ، ينطبق نفس الأمر

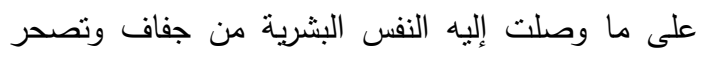
وجداني ، ويجب بذل المزيد من الجهد حتى تعود تلاك النفوس المتصحرة والمجدبة إلى نفوس خضراء معطاءة منتجة . وإذا كان التصحر البيئي والطبيعي مشكلة فإن التصحر الإنساني والنفسي والاجتماعي يعتبر مشكلة أعظم لما يحدثه ذلك الإنسان المجدب ( قَاجلٍ - أصابه القحط ) وجدانياً بالنفوس الإنسانية والبيئة الطبيعية. ولعل من أهم أسباب التصحر النفسى والاجتماعى هو

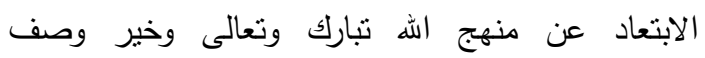
لأصحاب هذه النفوس ما جاء في قوله تعالى : (ثم قست الأن

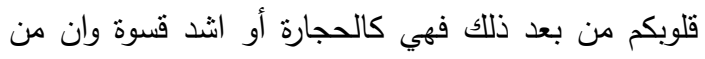

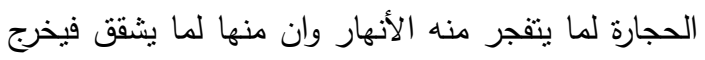

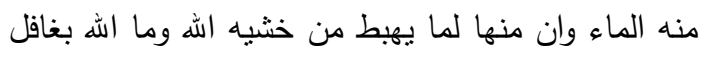

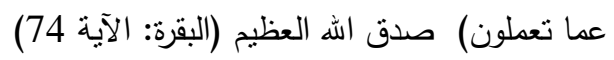


أكمل الاحوال ، ولهذ قال : واله يحب المحسنيين فهذا من

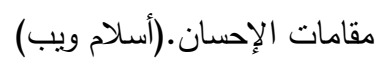

فالنفوس المتصحرة تعشق أذي الآخرين بدون أسباب حتى لو كان النعامل معها بالمعروف ولا تدرك الخير لأنها

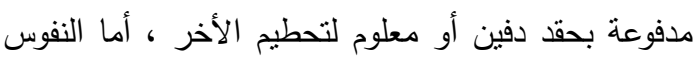

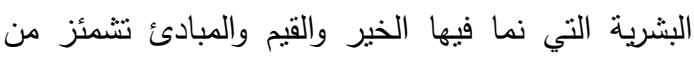
التصحر النفسي ، وقواعد الدين والأخلاق والقيم الإنسانية ولئية

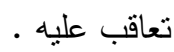

ومقاومة ظاهرة التصحر النفسي والاجتماعي مبادرة إنسانية مشرقة ترسم خطى أجيال الغد وتحقق التوازن

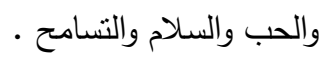

فعلى الإنسان إن يدرك دورة الحياة المعاصرة المليئة بالمتغيرات والمثيرات الني تصاحبها ردود فعل مختلفة

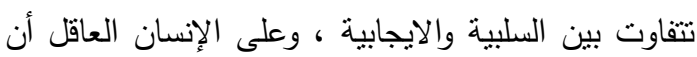

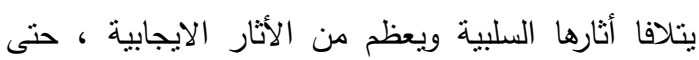

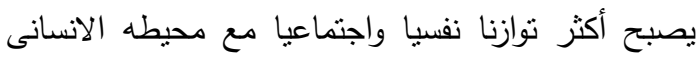

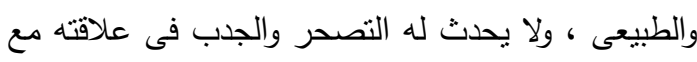

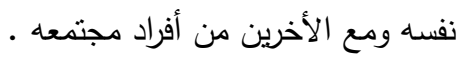

\section{1- 1 - 1 مشكلة البحث :}

يعد التغير الاجتماعي احد نتاج النظور العلمي

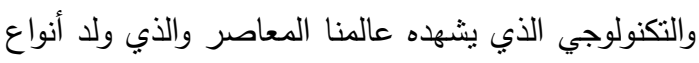

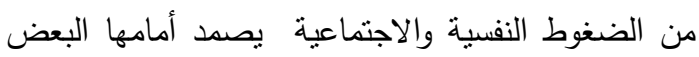
وينهار أمامها البعض الأخر الفنة والاجن

والإنسان كائن اجتماعي بنطبع بطبائع المجتمع الذي

تربى فيه. ولكي ينجح في حياته العملية عليه مواجهة

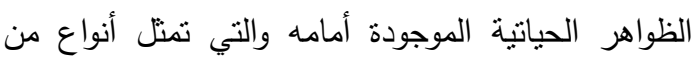
العقبات نتطلب منه التفاعل معها والتكيف لها و للقيم

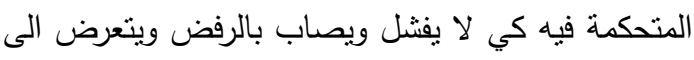
النبذ الاجتماعي حتى وان كانت هذه القيم والعادات لا لا لاني

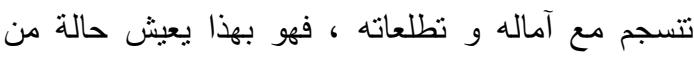

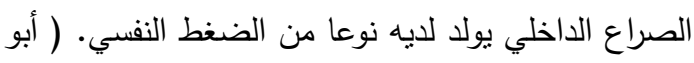

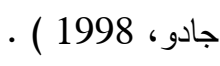

واضحا من الحكومات المنكررة بشبه جزيرة سيناء منذ الاحتلال الإنجليزي لسيناء وحتى الآن. (حسين، 2015) وتشير الدراسات البيئية والجغرافية إلى أن هناك فقد كبير من الأراضي الزراعية المنتجة تصل إضرارها المادية

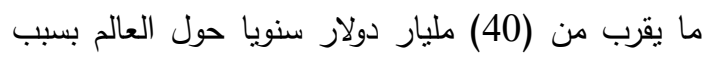
التصحر والجفاف وما تفعله العوامل المناخية والإنسانية فيها ( بيئتنا،2013 ) فإذا كان هذا وضع التصحر بالبيئة الطبيعية والتي

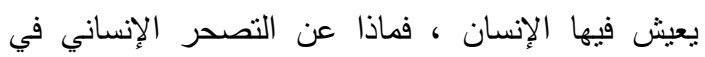

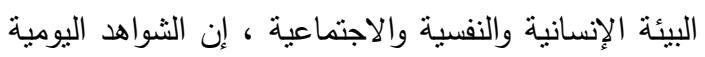

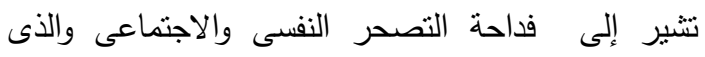
يظهر لما حولنا من حصاد للأرواح البشرية بالأيادي والئاعي ولائي

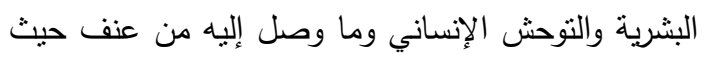

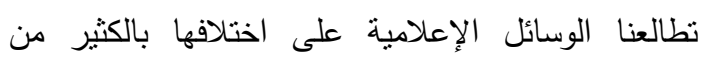

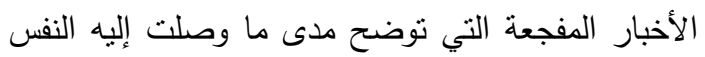

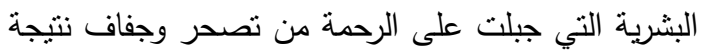
الإحداث غير الطبيعية .

وقد يرجع ذلك الأمر إلى حالة المناخ المتوتز الذي الذي

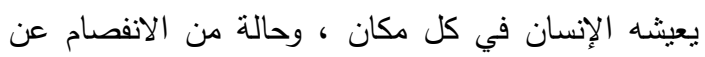
واقعه ، حالة مرغم عليها سواء بضغوط داخلية أو خارجية النى تقرض عليه حصارآ نفسياً ومعنويأ حتى أصبح المزاج العام خالي من دواعي البهجة والسرور وتنامى روح

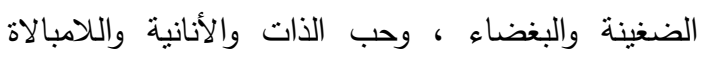
والسلبية والانظوائية والانسحاب من الحياة أو الانحسار وعدم النوافق على المستوى الثخصي والمجتمعي . ينمو التصحر وتزداد رقعته أنساعا إذا فقدت فضائل المعروف والمروءة والكرم والعفو والنسامح والسلام قال

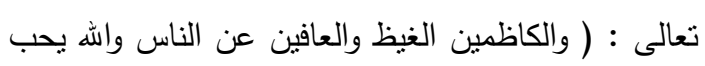
المحنين ) صدق اله العظيم (آل عمران:134) الكاظمين الغيظ أى لا يعملون غضبهم فى الناس بل يكفون عنهم

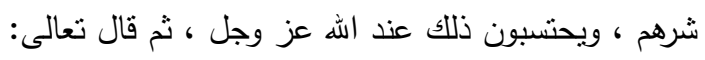

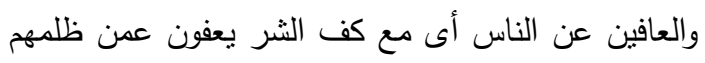
فى أنفسهر ، فلا ييقى فى انفسهم غضب على أحد وهذا 
الرجال في مدينة بغداد قد ارتكبوا جرائمهم قبل سن العشرين (باقر،1984) ووجد بلادك ( black, 1979 ).

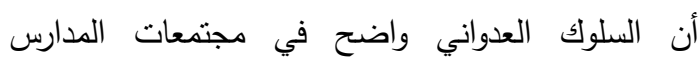

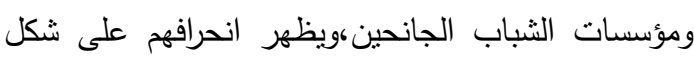
سلوك عدواني ورفض مستمر للسلطة والعلاقات العائلية . وقد ظهرت في المجتمع المصري في الآونة الأخيرة

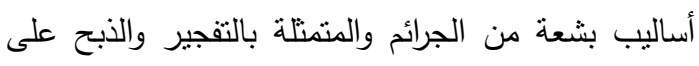

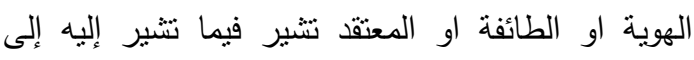

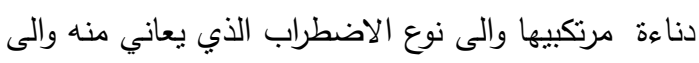

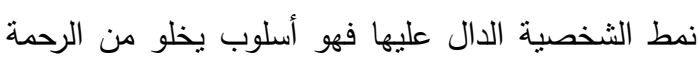

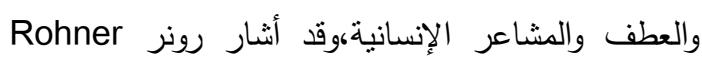
(1986,) إن الأطفال الذين حرموا من العطف وأدركوا الرفض وعدم التقبل من قبل الوالدين يبدون أنماطا سلوكية

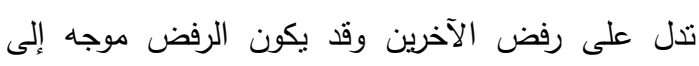

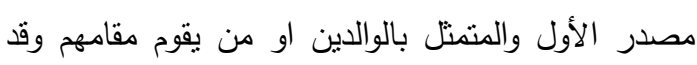
أطلق عليه رونر بالرفض المضاد.

ولما كانت شريحة الثباب أكثر الشرائح الاجتماعية

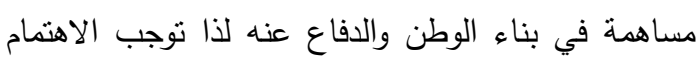

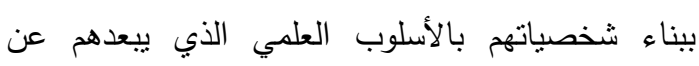

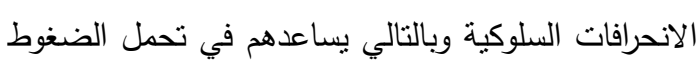

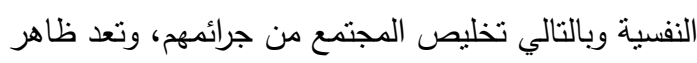
التصحر النفسي والاجتماعي من المشكلات الني يعاني

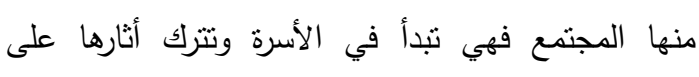

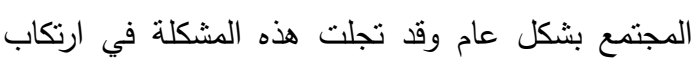

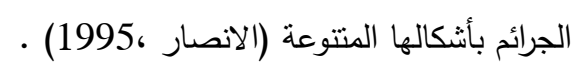

إننا أمام مشكلة حقيقية تتمثل فى ضعف العواطف والأحاسيس الإنسانية التي تجعل سلوكهم جافا خاليا من النمام

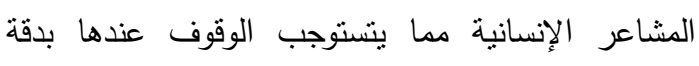

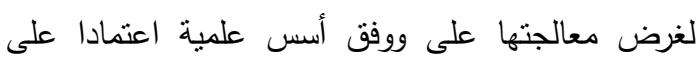
الدور الذي يمكن أن تلعبه هذه الشريحة المهمة في

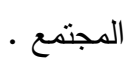

ومع تفاقم مشكلة الارهاب فى سيناء وعزم الدولة على

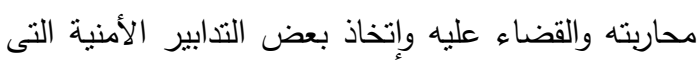

ويعد الثباب الثريحة الأكثر تأثرا بالضغوط النفسية

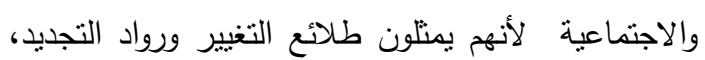

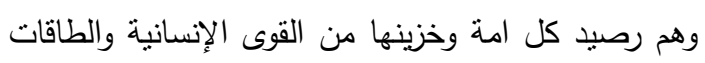

$$
\text { البشرية البم رونية }
$$

والضغوط النفية والاجتماعية التي يتعرض لها الثباب غالبا ما نؤدي إلى أزمات نفسية قد نرقي أحيانا إلى مستوى الاضطرابات الحادة التي تنطلب مواجهة متفهمة ومعالجة جادة، قد يثعر الثاب معها بالغربة والضياع داخل ذاته وداخل مجتمعه الذي يعيش فيه،هوقد

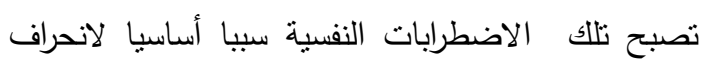

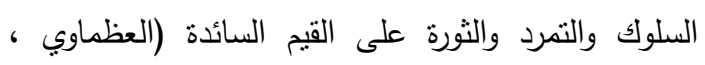

وقد تعرض الثباب السيناوى فى مصرإلى أنواع

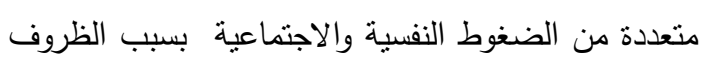

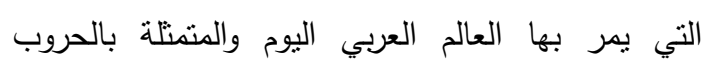

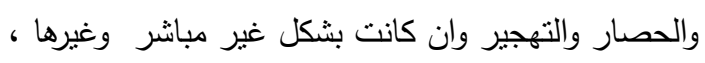

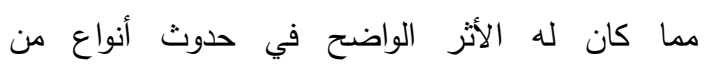
الاضطرابات النفسية والاجتماعية في مختلف شرائحه

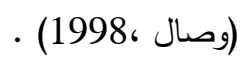

وقد برزت أنماط من المشكلات النفسية و الاجتماعية نتيجة الظروف الحياتية الصعبة والتي أثرت بشكل كبير

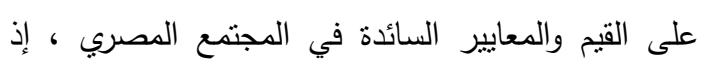

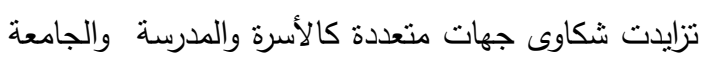
وغيرها من المؤسسات الأخرى في الدولة من نخلي شرائح

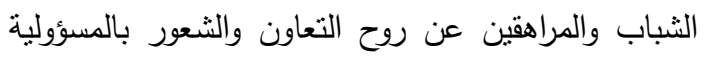

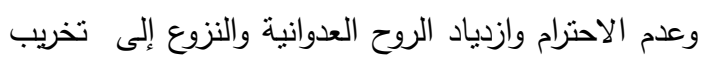

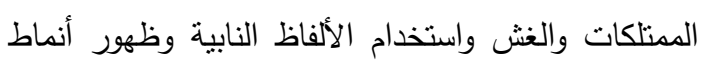

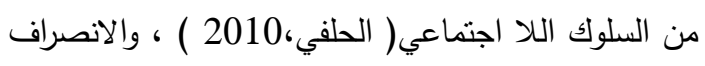
إلى اللهو والصخب وقلة الاهتمام بالعلم وعدم احترام مشاعر الآخرين والسلوك الجاف عاطفيا والاندفاع وراء نزواتهم الخاصة (العبيدي ، 1995). وبناء على العلاقة بين الأنماط السلوكية وحدوث الجريمةفي المجتمع العراقى وجدو (87\%)من نزلاء إصلاحية 


$$
\begin{aligned}
& \text { وبناء على ما تم ذكره فإن أهمية البحث الحالي تتضح }
\end{aligned}
$$

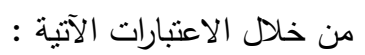

$$
\begin{aligned}
& \text { 1- الكثف عن ظاهرة التصحر النفسي والاجتماعي لاى الاعي } \\
& \text { الثباب المصري ( السيناوى ) كون المصطلح يدرس التصاعي }
\end{aligned}
$$

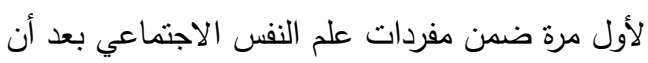

$$
\begin{aligned}
& \text { كانت دراسته مقتصرة في العلوم الطبيعية. }
\end{aligned}
$$

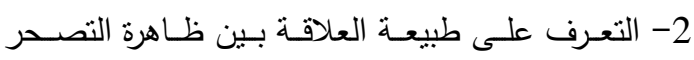$$
\text { النفسي والاجتماعي وأسلوب تعامل الثباب مع الأهل }
$$$$
\text { و إفراد المجتمع }
$$

3-تناول البحث لثريحة مهمة في المجتمع يعتمد عليها

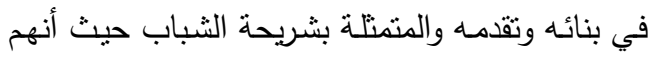

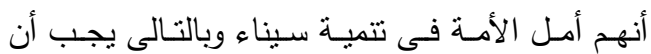

$$
\text { يكونوا مؤهلين نفسيآ وإجتماعيآ . }
$$

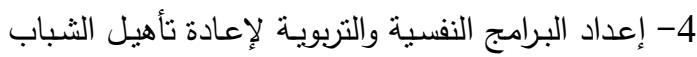

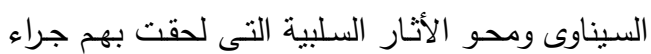

فترة تطهير أرض سيناء من الأرهاب الأسود .

$$
\text { 4- أهد(ف البحث: }
$$

$$
\text { يستهدف البحث الحالي ما يأتي: }
$$

1- التعرف على أسباب التصحر النفسي الاجتماعي .

2- - التعرف على خصائص الثباب بعينة الدراسة .

3- التعرف على السمات الثخصية للإفراد الذين يعانون

$$
\text { من التصحر النفسي والاجتماعي . }
$$

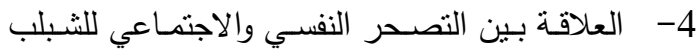

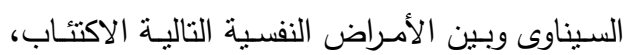

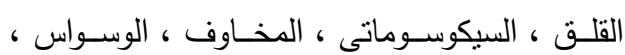

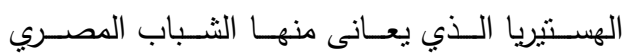

$$
\text { (السيناوى ). }
$$

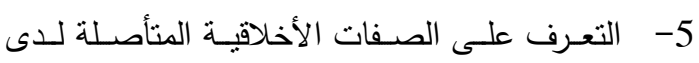

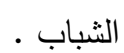

6- التعرف على الصفات غير الصستحبة والتى يكرها

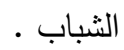

7- التعرف على الخدمات التى يحتاجها الثباب فى .

المنطقة .
قد تعوق حركة الأفراد وسبل معيشتهم ووقوع حوادث

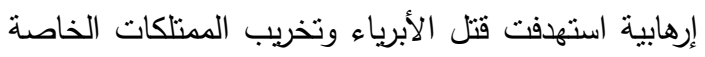
والعامة ، الأمر الذى أصبح فيه أفراد المجتمع أكثر قلقآ

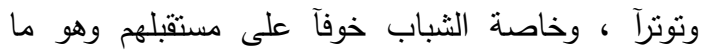
انعكس على بعض سلوكياتهم وتصرفاتهم والتى اتسم

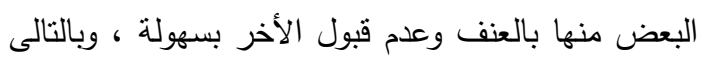

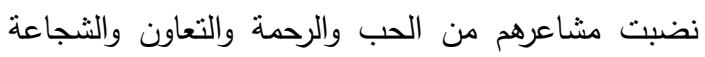
وهو ما كان يميز الثخصية السيناوية ، فإلى أى درجة أصاب التصحر النفسى والاجتماعى الثباب السيناوى هذا ما يسعى البحث التحقق منه . ل 2- تسأولات البحث : - - ما هي أسباب التصحر النفسي الاجتماعي ؟ - ماهى خصائص الثباب بعينة الدراسة ؟

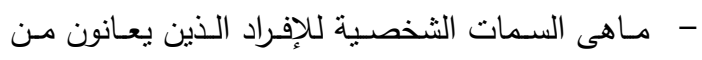
التصحر النفسي والاجتماعي ؟

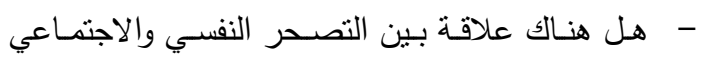

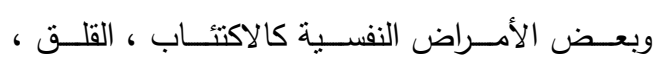

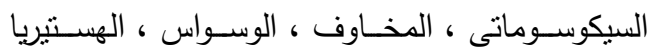
الذي يعانون منها الثباب المصري ( السيناوى)؟ - - ماهى الصفات الأخلاقية الهتأصلة لدى الثباب ؟ - ما هى الصفات غير المستحبة والتى يكرها الثباب ؟ - ماهى الخدمات التى يحتاجها الثباب فى المنطقة ؟

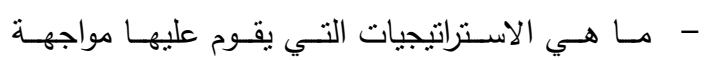
التصحر النفسى والاجتماعى والوقاية هنه ؟

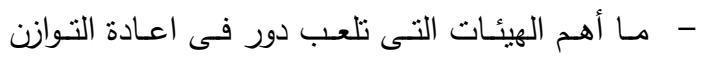

$$
\text { النفسى والاجتماعى ؟ ل النمات }
$$

$$
\text { 3- أهمية البحث : البح البية }
$$

إن أساليب المعاملة الوالدية الخاطئة في التربية تسهر

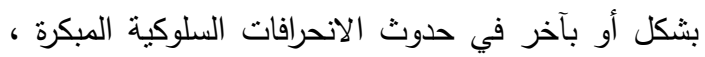

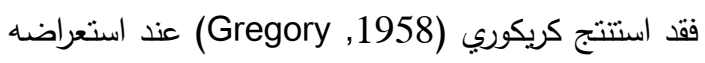
للبحوث العلمية في مجال التربية وعلم النفس وجود

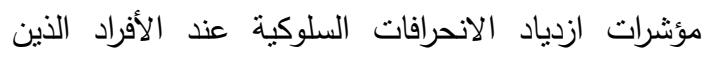

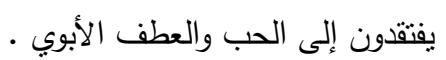


وإن سوء العلاقات بين الوالدين وأسلوب المعاملة غير

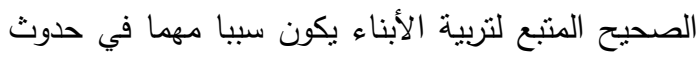

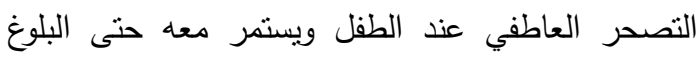

. ( Adamsm.Suker.1993)

$$
6 \text { - منهج البحث : }
$$

استخدم المنهج الوصفي (الأسلوب المسحي) كونه : يناسب طبيعة المشكلة الددروسة ويساعد في تحقيق لهني

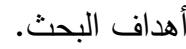

\section{* - هدف المنهج الوصفي :}

تهذف البحوث الوصفية إلى وصف ظواهر أو أحداث أو أثنياء معينة وجمع الحقائق والمعلومات والملاحظات عنها ووصف الظروف الخاصة بها وتقرير حالتها كما توجد عليه في الواقع.( نوفل وآخرون، 1994) - أداة البحث : اعتمد البحث على عدد من المقاييس لجمع البيانات من المبحوثين منها : 1- مقياس للتصحر النفسي والاجتماعي (ميدل سكس) • 2- بنـاء مقيـاس الرضـا عـن الـفس والمكـان والآخـرين والمجتمع وقواعد الضبط الاجتماعى .

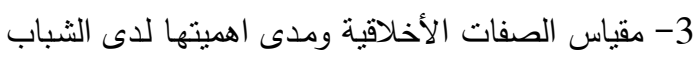
السيناوى ، والصفات غير الأخلاقية ومدى كرهم لها.

4- قياس الخصائص الثخصية للثباب المبحوثين .

$$
\text { 7- الموجهات النظرية : }
$$

من الأصول المنهجية في البحوث الاجنماعية أن الن النهابه النظرية ينبغي أن نوجه البحث ولا بد أن يساهم البحث

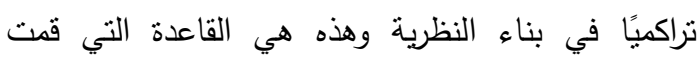
بنطبيقها خلال المراحل السابقة.

وأحاول في هذه البحث الالتزام بها من خلال تحليل البيانات الكمية والكيفية في ضوء التكامل بين الاتجاهين. ولذلك أبدأ بتحديد مواقع الالتقاء بين أدوات البحث بالدرجة الأولى ثم انتقل إلى تعين جوانب الاتفاق

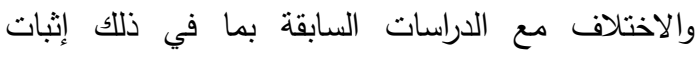
عناصر التقرد في البحث بعد ذلك أبحث في مدى علاقة
8- التعرف على أستراتيجيات مواجهة التصحر النفسى

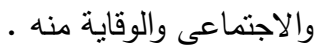

9- التعرف على أهم الهيئات التى تلعب دور في اعلى التادة

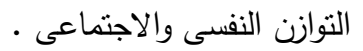

5- الاراسات السابقة :

توصلت دراسة كرير (1964, Greer) الى انه كلما كان السلوك المنحرف أكثر حدة كان احتمال وجود حرمان عاطفي من قبل الوالدين ، وأثارت دراسة اولتمان وفريدمان التحان وحرد حردان (Altman and Friedman) العاطفي بحد ذاته تكون أهميته اقل في نكوين الثخصية

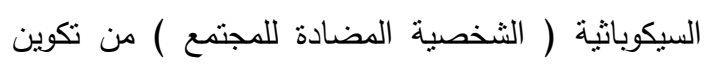

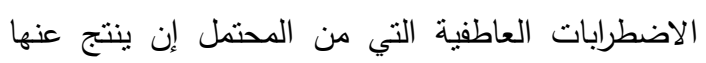

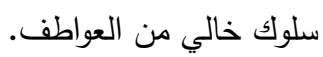
واستتتج ماكوردوماكورد (Mecord and Mecord) عام 1960 أن الحرمان العاطفي والرفض القاسي من قبل

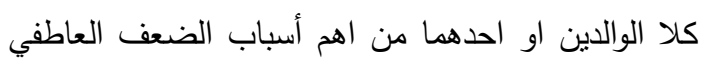

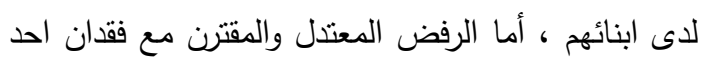

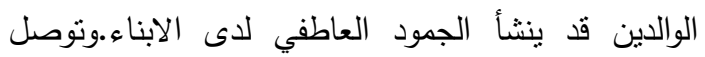

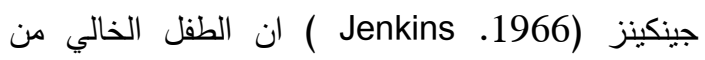

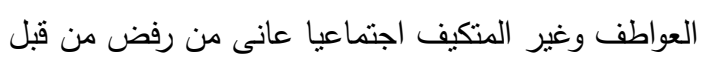
الوالدين بصور منواصلة خصوصا من جهة الأم (جابر ، . (1998

وقد أيد ذلك كل من بنيت وأندري (Anet and

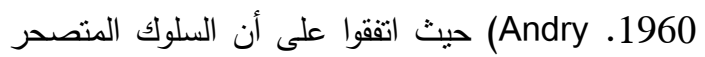
عاطفيا مرتبط بأساليب التأديب والتكيف الاجتماعي الغريبة والمتقلبة ( Hare ، Ha ). وإن الأسرة المتفككة أو التي تعاني من فقان أو

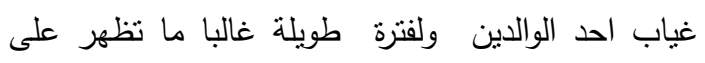
بعض أبنائها سلوكيات جافة عاطفيا،وهذا بعني قطع

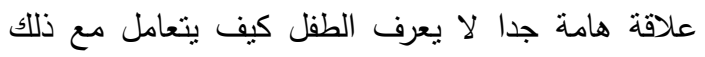

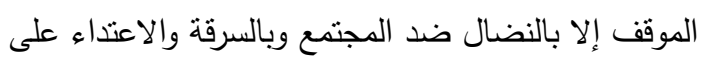
الآخرين دون الأخذ بنظر الاعتبار أية قيمة لمشاعرهم

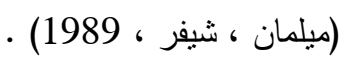


وتوفير الخدمات الضرورية ، كان رد الفعل الطبيعى

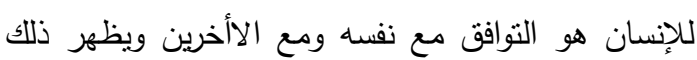

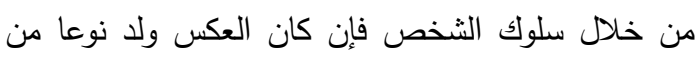

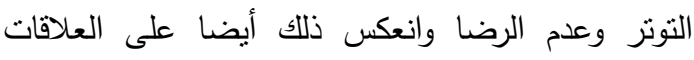

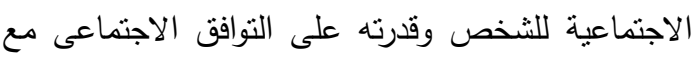

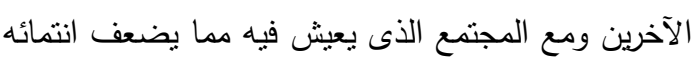
لا سرته ومجتمعه .

نظرية القسر أو القيد السلوكى : هذه النظرية واضحة فى

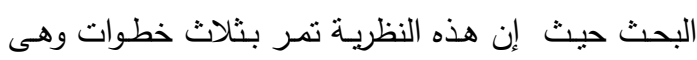

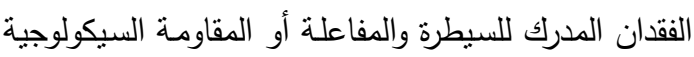
ثم تعلم العجز وانعدام الحيلة.( العتيق ، 1996)

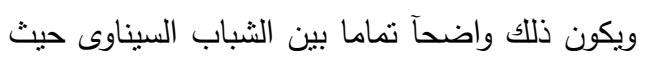
انهم لا بستطيعوا السيطرة على البيئة المحيطة بهم نتيجة

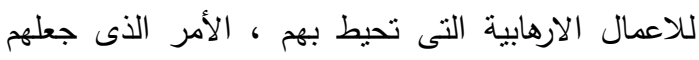

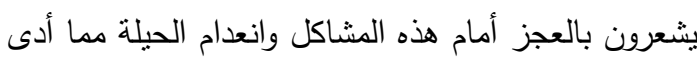
كل ذللك إلى إصابة نسبة كبيرة من الافراد المبحوثين بالإكتئياب والقلق وبعض الأمراض النفسية الأخرى النى قد

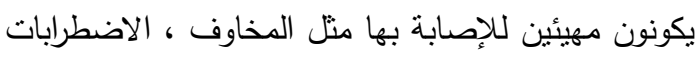
السيكوسوماتية ، الوسواس ، الهستيريا .

$$
\text { 8- المفاهيم : }
$$

التصـحر : هو تدهور إنتاجيـة الأراضـى والميـاه والنبـات

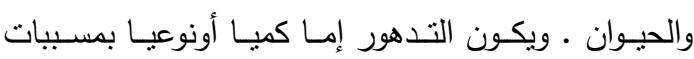

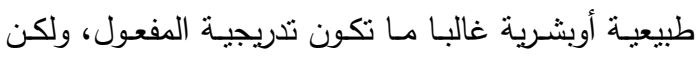
عواقبهـا تتجـاوز المسـويات المحليـة للمسـنويات الوطنيـة وربما الإقلمية والعلمية.( طاحون ، 2012)

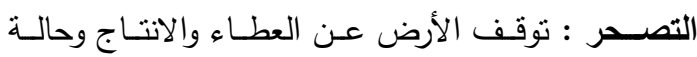
الجدب والجفاف والقحط التى تجعل الحياة صعبة وقاسية.)

$$
\text { دعبس ، } 2004 \text { ) }
$$

التصـر النفسي : هو عدم التوازن النفسي والإحساس

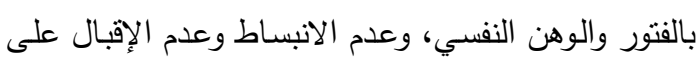

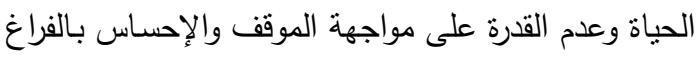
العاطفي والاجتماعي، وافتقاد المعنى الحقبقي للحياة وافتقاد العياد الأمـل ـ يعيش الإنسـان المنصـر نفسيا في قلق وحزن
النظريات بوقائع البحث وإلى أي حد يمكن توظيف النظرية في خدمة التحليل الميداني المبانشر للمعلومات الكيفية لكئية والنتائج الكمية الإحصائية وكيف يمكن للثواهد الدافعية أن الن النيل

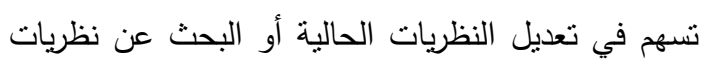

وتعرف النظرية بأنها محاولة لتقديم العلاقات الكامنة التي يفترض وجودها بين المتغيرات التي تصنع حدثًا أو نظامًا معينًا في شكل رمزى ـ ( عثمان ، 1994) تمثل النظرية الإطار الفكري أو الفلسفي الذي ينت من

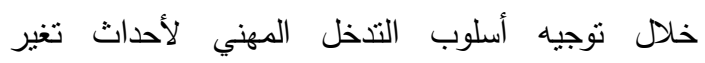
اجتماعي أو توجيه أساليب الممارسة المهنية عن مواجهة

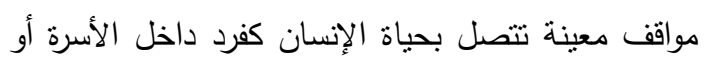
كعضو في جماعة أو عدة جماعات أو كمتردد ومستقيد

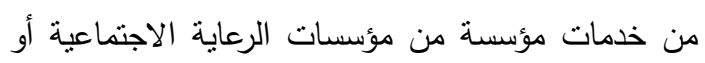
كمواطن داخل المجتمع · ( مختار ، 1995 ) وحيث إن البحث الحالى يلعب دور فى أعادة التوازن

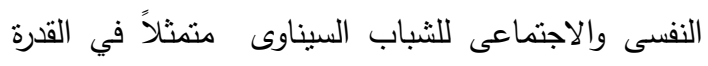

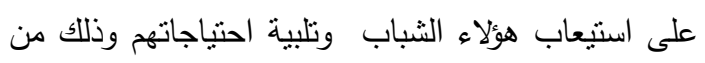
خلال تفاعل اجتماعي يشبع حاجاتهم في إطار أهداف الفئ المجتمع ، وفي ضوء القيم الاجتماعية السائدة. لذا فإن البحث الحالى قد انطلق من معطيات نظرية الحاجات . لإن وذللك مع توضيح كيفية الاستفادة منها في إثباع

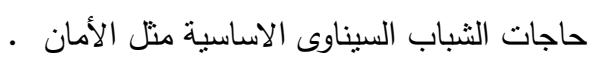
نظرية الحاجات : مضمون نظرية ماسلو أن الحاجات أو

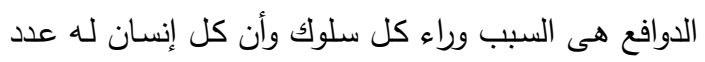

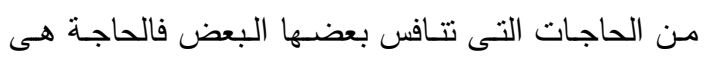

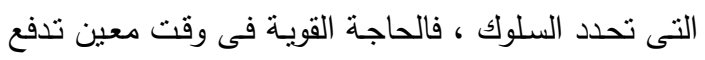

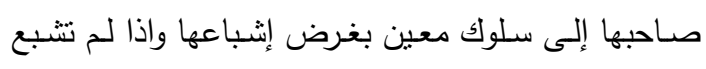
يشعر الإنسان بالضيق والتوتر · ( Thomas.1976 ) ورتب ماسلو الحاجات نرتيبأ تصاعديا تبدأ بالحاجات

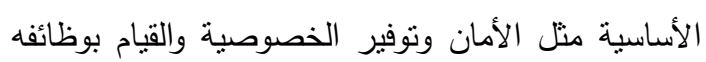


فيها الإنسان قادرآ على مواجهة الحياة وتحمل مسئولياتها وضغوطها الإقتصادية والاجتماعية .

تعريـف الوسـواس : فكر متسـلط وسـوك جبرى يظهر

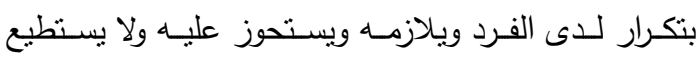

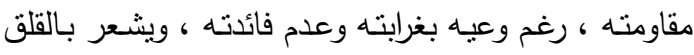

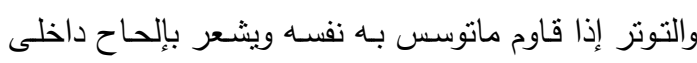

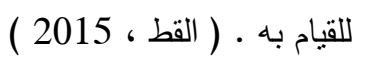
تعريف الهستيريا : تعنى عصـاب معقد يتخذ عددا من

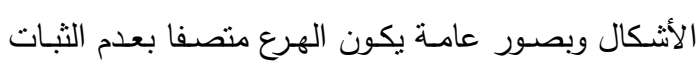

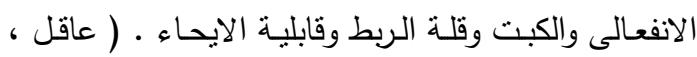

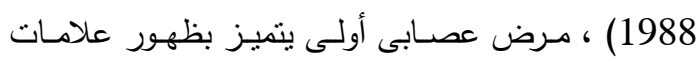

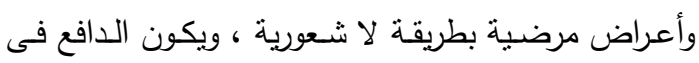

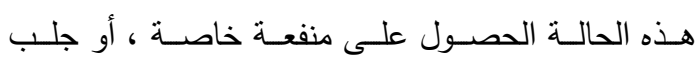
الأهتمام ، أو الهروب من موقف خطير أو تركيز الأهتمام

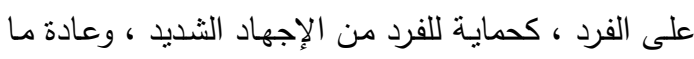
يظهر هذا المرض فيى الثخصية الهستيرية التى تتميز

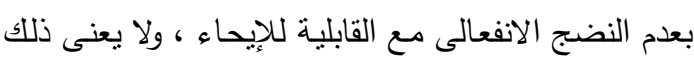

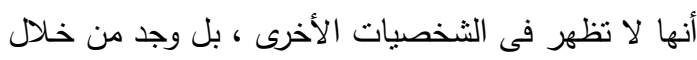

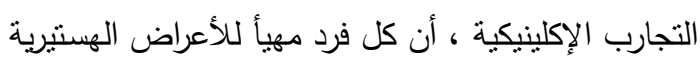

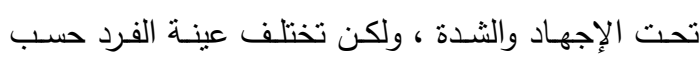

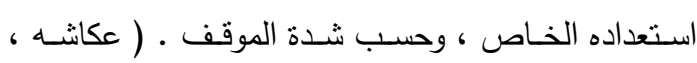

تعريف الأكتئاب : هو حالة من الحزن الثديد المستمر

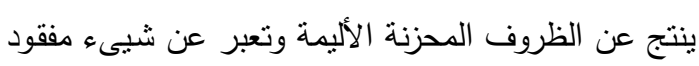

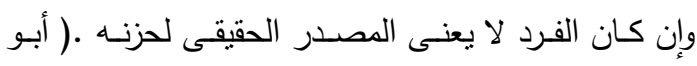

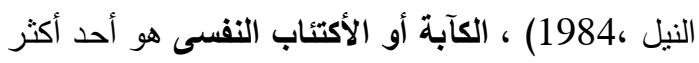

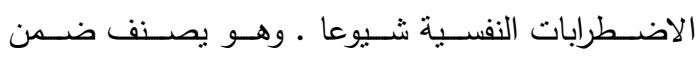
الاضطرابات النفسية التى تتسم بخلل فى المزاج وأهم ما لـا

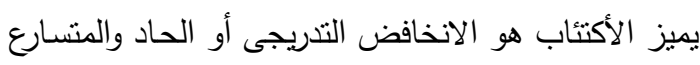

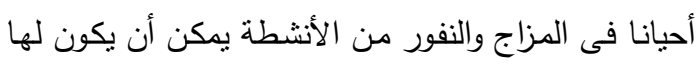
تأثنير سلبى على أفكار الثخص وسلوكه ومثاعره ونظرته إلى العالم والرفاهية المادية . (Sandra . 1997) ، حالة الثئل

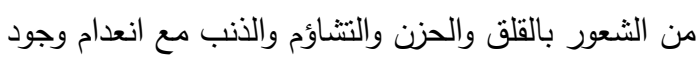

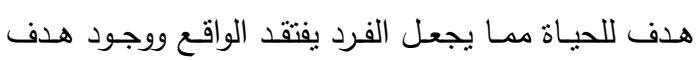

شديد دائم الاتشغال وعدم الرضا عن النفس وعن الآخرين

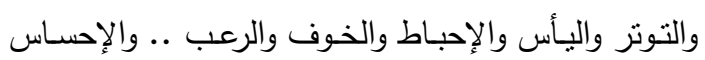

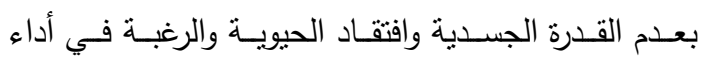
الأعمال كما كان في السابق ... بعيش بلا أمل ولا طموح

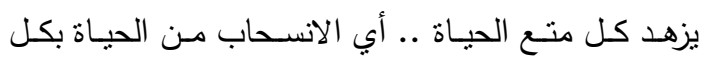
أحزانها وأفراحها بكل آمالها وآلامها. ( دعبس،2006 الانس ) التصدر النفسي والاجتماعي : يرى الباحث

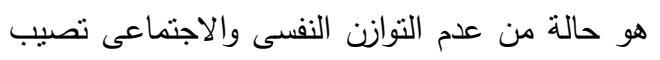

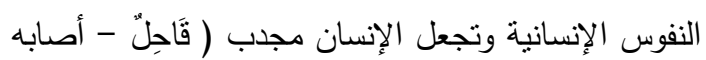

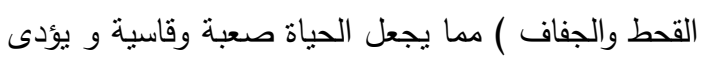
الى افتقاد الامل واليأس من الحياة والاحساس لبعل بعدم

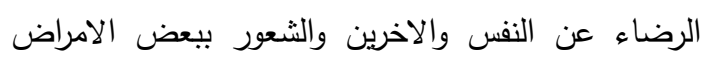
النفسية كالاكتئاب ، القلق ، والاضطرابات السيكوسوماتية،

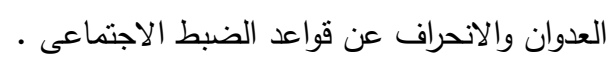
التعريف الإجرائي للتصحر النفسى والاجتماعى : هو حالة من عدم النوازن النفسي والخلل الاجتماعي لإحئي

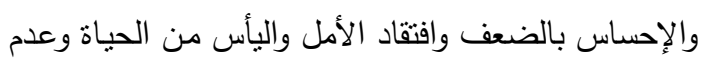

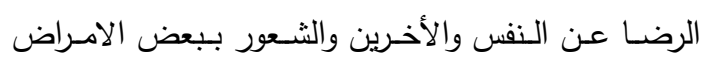

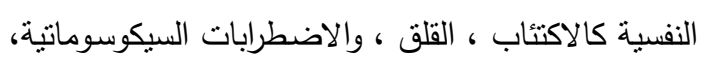

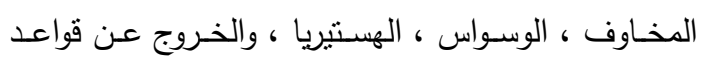

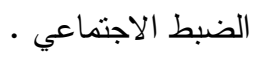
الثباب : يرى علماء النفس إن الثباب يعني: الاقتراب من النضـج الجسمي والعقلي والنفسي والاجتماعي، ولكنه

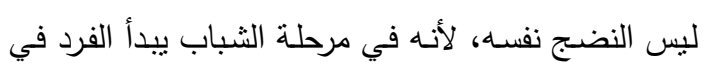

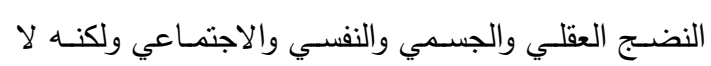

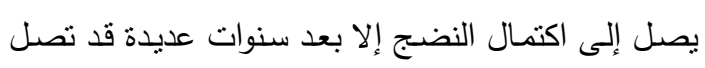

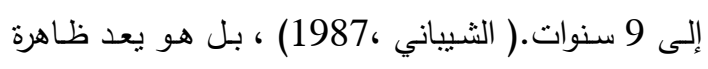
اجتماعية تشيرإلى مرحلة من العمر تعقب مرحلة المراهقة،

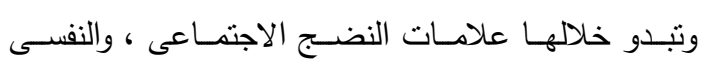

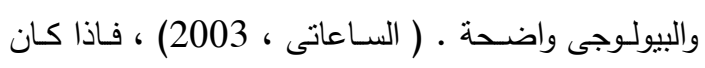

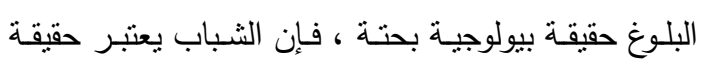
اجتماعية بالأساس.( ليلة ، 2004 )

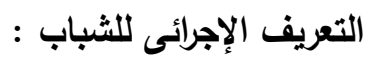

هى المرحلة العمرية ما بين (18- 35 ) والتى يكون 
بعد نفسى وبعد جسـى . أى ان صـاحبه عـانى مشـاكل

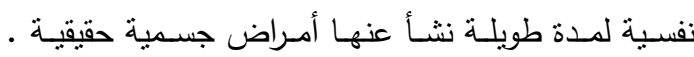

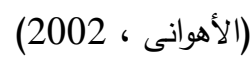
العدوان: سلوك مقصود يستهدف ألحاق الضرر أو الأذى بالغير وقد ينتج عن العدوان أذى يصيب إنسانا أو حيوانيا

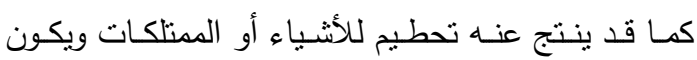
الدافع وراء العدوان دافعآ ذاتيا.( مجيد، 2012 ) الضـبط الاجتمـاعى : أنـه العمليـة التى يسنطيع المجنـع بواسطتها السيطرة على أفراده وتنظم سـوكهم مـن خـلال مجموعة من الوسائل بالثكل الذى يؤدى إلى اتساق هذا

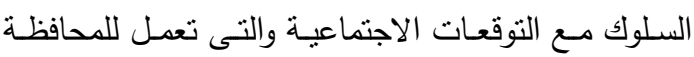
على اسـتمرارية المجتمـع ونمـوه فـى الأوضـاع الاعتياديـة وتلافى التخلف الذى يحدث في بعض مؤسسـاته خـلال

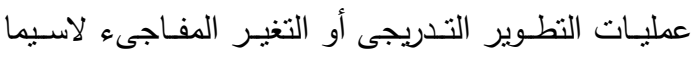

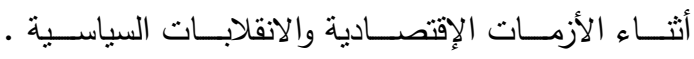
(القريشى، 2012 ) (

$$
\text { 9- مجالات البحث : }
$$

المجال المكاني : شبه جزيرة سيناء هي منطقة حيوية تقع بين زراعي البحر الأحمر بين خليج السويس غربا وخليج العقبة شرقا وتتوسط قلب العالم العربي وتربط بين شطريه في أفريقيا وآسيا.

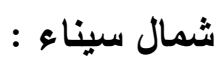
محافظة شمال سيناء من محافظات مصر وعاصمتها العريش تقع فى الثـمال الثرقى لمصر بين خطى طول (32 ، 34) شـرقآ وخطـى عـرض (29، 31 ) شـمالآ

ويحدها من الثمال البحر المتوسط بطول (220 كم ) أما جنوبا فخط يمتد من جنوب مصر منتلا حتى راس النقب ويحدها من الثرق الحد السياسى لمصر مـع قطاع غزة أما غربا فيمثل خط ممتد من مصر متلا جنوبا حتى بالوظة شمالا ولسيناء أهميـة أستراتيجية كبرى خاصـة شـمال سيناء

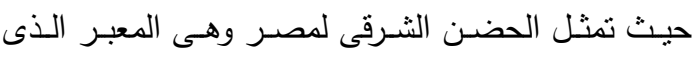

للحيـاة ـ ( القذافى ،1998 ) ، قـد يثـعر المعـانون مـن

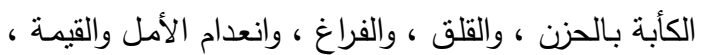

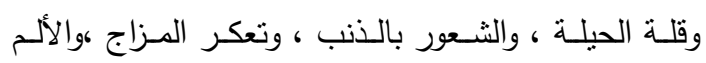
المعنـوى ، والاضـرراب ـ فقد يفقدون الاهنمـام بنشـطات

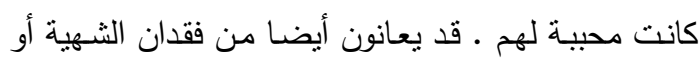

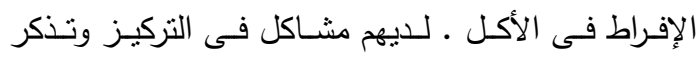

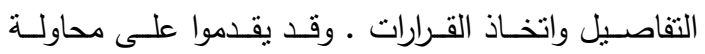
الانتحار أو الفكير فيه أيضا .

المخاوف : حالة وجدانية من الخشية وترقب الشر بموقف أو موضوع بيئى فإذا مات أزيل كل منهما فإن تلك الحالة • تغد وتتتهى نوصوع أما القلق : هو حالة من توتر شامل ومستمر نتيجة توقع خطر أو تهديد فعلى أو رمزى قد يحدث ويصحبها خوف هون غامض أو اعراض نفسية ، جسمية وقد ينتج القلق بسبب التبائ

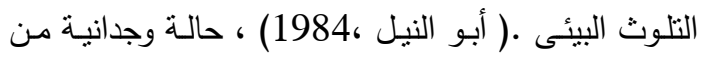
الخشية وترقب الثـر لا ترتبط بموقف أو موضـوع بيئى معين وهو شعور عام هائم طليق كما يمكث مع الفرد فى كل الأوضاع والمواقف وقد يكون الخوف عامآ غير محدد

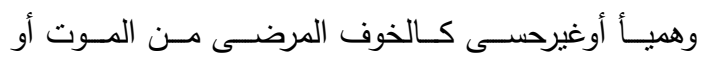

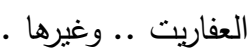

يمثل مرض الخوف حوالى 20\% من مجموع مرضى العصــاب ثيحـدث الخــوف بنسـبة أكبرلــدى الأطفــال والمـراهقين وصـغار الراشدين والخوف ينتشر لدى الإنـاث أكثر منـه لـدى الذكور .( الأهـوانى ، 2002)، أنـه حالـة نفسية تظهر على شكل نوتر بشكل مستمرنتيجة شعور الفرد بوجود خطر يتهدده ومثل هذا الخطر قد يكون موجود

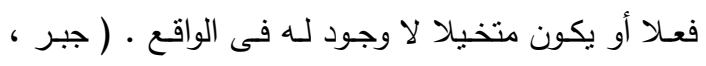

الاضـــرابات السيكوســوماتية : نقصــــ بالاضــطرابات السيكوسوماتية تلك الأمراض الجسمية الناشئة عن أسباب نفسية فقرحسة القولـون ، وارتفـاع ضـغط الدم ، والصــاع النصـفى ، واضـطراب العـادة الثــهرية ، وحساسـية الجلد ولـ وحب الثباب ..الخ ، وهو يعنى اى اضطراب ذى بعدين، 
الخاصـة بالتسلسل المنطقى للاسئلة والوضوح حتى تكون

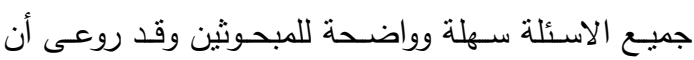

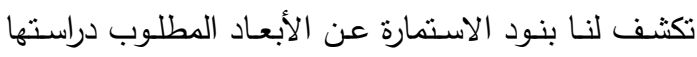

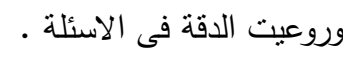

- ادوات سبق تصميمها :

قام الباحث بأختيار مقياس ميدل سكس لقياس الحالة النفسية لافراد العينة ويشتمل ذللك المقياس على بالى 48 سؤالآ

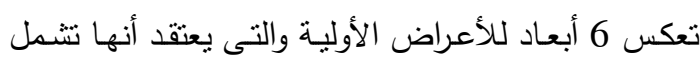

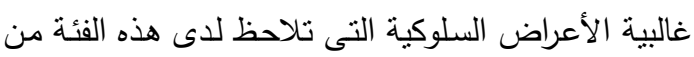

$$
\text { نتائج البحث : }
$$$$
\text { اولآ : خصائص عينة البحث }
$$

تثير النتائج بالجدول (1) إلى أن الغالبية القصوى من البن

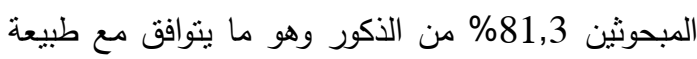

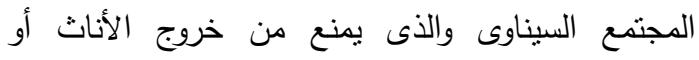
تجاوبهم مع البحث العلمى ، فيما تبلغ نسبة الأناث ، 18,7

وأن ما يزيد عن خمسهم 43,4 يقع فى الفئة العمرية

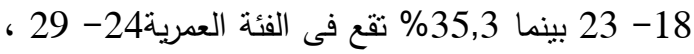

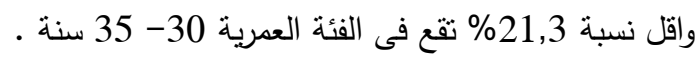
وما يزيد عن نصف المبحوثين 56,0\% من حملة المؤهلات المنوسطة ، بينما 16,0\% من حملة المؤهلات العليا ، وكانت نسبة الحاصلون على دراسات عليا أو تعليم

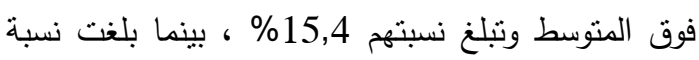

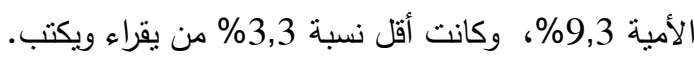
مايزيد عن ثلاثة أرباع المبحوثين 78,7\% متزوجون

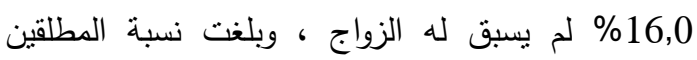

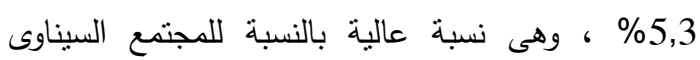

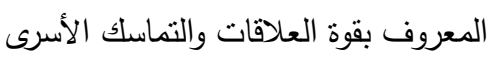

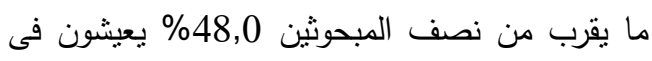

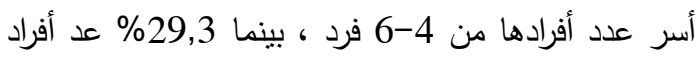

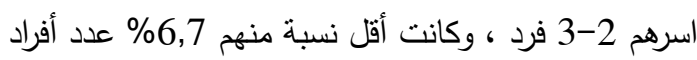

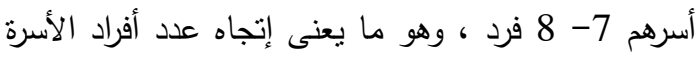

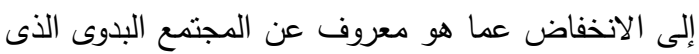

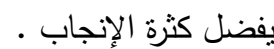

عبرت منه معظم الغزوات التى أستهدفت مصر سواء فىى التاريخ القدبم أو الحديث

وتتمل محافظة شمال سيناء على ست مراكز إدارية هى : ( رفح ، الثيخ زويد ، العريش ، بئر العبد ، نخل ،

الحسنة )

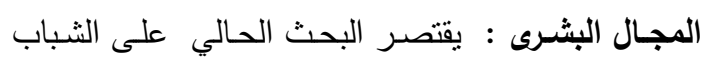
المصري ( السيناوى ) حيث تم اختيـار عينـة عشـوائية

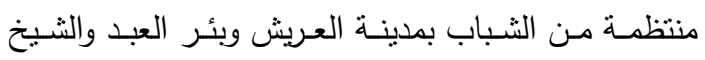

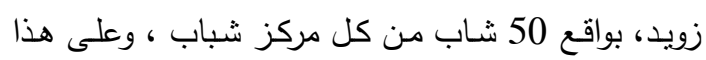

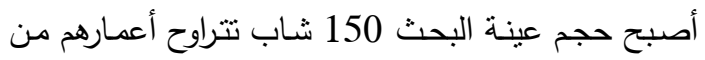
18- 35 عامآ وفقآ لبعض النعاريف التى حددت الثباب عمرياً بهذا السن عاما وفن

المجال الزمني : استغرق جمع البيانات قرابة شهرين خلال الفترة من أكتوبر - نوقمبر 2016م المجير جيع النيات

10-صدق المقياس ( الرضا )

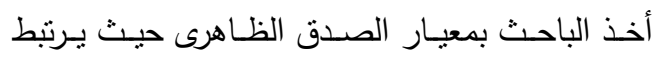

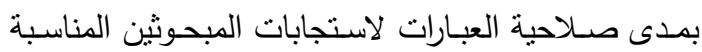

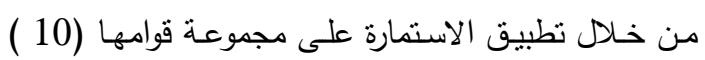

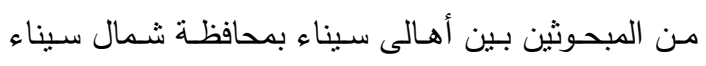

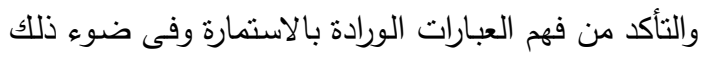
تم تعديل بعض العبارات ، ثم قام الباحث بتطبيق الاشتمارة

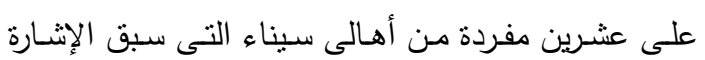

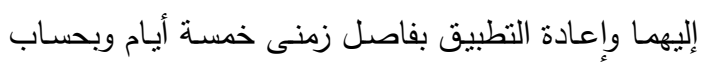
معامل ارتباط بيرسون كانت قيمته 0.78

\section{1-ثبات المقياس ( الرضا)}

تم تطبيق الاستمارة بفارق زمنى اسبوعين على عينة

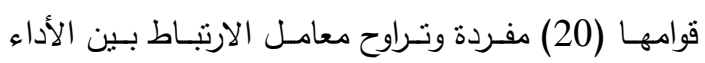
الاول والثانى بين 0.80 و 0.92 وكـان معامـل الثبـات ككل 0.86

\section{• الأستمارة فى صورتها النهائية :}

بعد إجراء التعديلات التى سبق ذكرها صيغت أسئلة الاستمارة فى صورتها النهائية مع مراعاة جميع الاعتبارات 
أيضآ المجنمع المصرى بصفة عامة ، يليها ما يقرب من ربع المبحوثين 24,7\% عمال ، وأقل من خمس المبحوثين 20,0\% بدون عمل وبالتالى ليس لايهم دخل مادى مما يجعلهم عرضة لكثير من عدم التوافق النفسى والاجتماعى لئى كما أن الثطر الأعظم من كتلة البطالة بتمنل فى بطالة الثباب وتدهور الاوضاع الاقتصادية والاجتماعية والنفسية وبالتالى هؤلاء الثباب بدل من كونهم يدى عاملة وطاقة جبارة فى دعم الاقتصاد أصبحوا يشكلون عبئً أقتصاديآ ثقيلا على المجتمع ، وتبلغ نسبة الثباب المزارعين

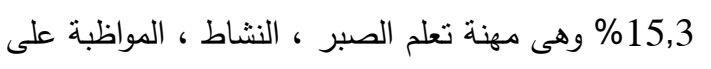

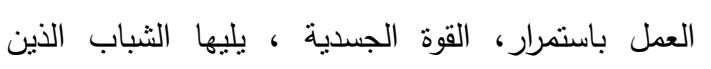

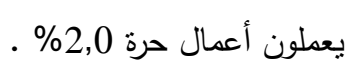

بينما كانت نسبة الذى لا يحصلون على عائد مادى ويعتمدون على والديهم 23,3\% ، فى حين 22,7\% لفئة من 1000- أقل من 2000 جنيه ولئ تقاربت نسبة المبحوثين على جميع فئات مستوى

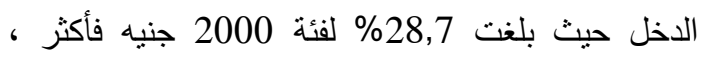
بينما بلغت 25,3\% لفئة أقل من 1000 جنيه شهريا ،

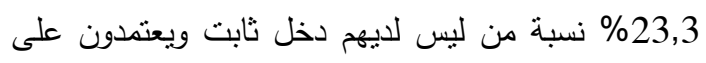
والديهم، 22,7\% لفئة من 1000 - أقل من لين لائم 2000 جنيه. كما نشير البيانات الواردة بالجدول(1) أن مايزبد عن تلثى المبحوثين 38,0\% من الموظفين وهم فقراء الطبقة الوسطى بالرغم أن لايهم دخل ثابت الاإن هناك حالة من التضخم ( ارتفاع الاسعار ) التى تقضى على الأخضر

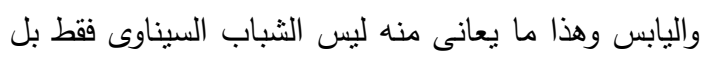

جدول ( 1 ) توزيع المبحوثين وفقآ لخصائصهم المدروسة

\begin{tabular}{|c|c|c|c|c|c|}
\hline$\%$ & 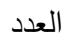 & الخصائص & $\%$ & 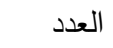 & الخصائص \\
\hline & & & & & النوع \\
\hline & & عدد أفراد الاسرة & 81,3 & 122 & ذكر \\
\hline 29,3 & 44 & $3-2$ & 18,7 & 28 & أنثى \\
\hline 48,0 & 72 & $6-4$ & & & \\
\hline 6,7 & 10 & $8-7$ & & & ق ق قئات السن \\
\hline \multirow[t]{3}{*}{16,0} & 24 & لم يسبق له الزواج & 43,4 & 65 & $23-18$ \\
\hline & & & 35,3 & 53 & $29-24$ \\
\hline & & الدخل الثهرى & 21,3 & 32 & $35-30$ \\
\hline 25,3 & 38 & أقل من 1000 & & & \\
\hline 22,7 & 34 & 1000 - أقل من & & & الحالة التعليمية \\
\hline 28,7 & 43 & 2000 & 9,3 & 14 & أمى \\
\hline \multirow[t]{4}{*}{23,3} & 35 & 2000فأكثر & 3,3 & 5 & يقراء ويكتب \\
\hline & & & 56,0 & 84 & متوسط \\
\hline & & & 16,0 & 24 & مؤهل جامعى \\
\hline & & المهنة & 15,4 & 23 & دراسات عليا وفوق المتوسط \\
\hline 38,0 & 57 & موظف & & & \\
\hline 24,7 & 37 & 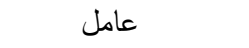 & & & الحالة الاجنماعية \\
\hline 20,0 & 30 & بدون عمل & 78,7 & 118 & متزوج \\
\hline 2,0 & 3 & أعمال حرة & 16,0 & 24 & أعزب \\
\hline 15,3 & 23 & مزارع & 5,3 & 8 & مطلق \\
\hline
\end{tabular}

المصدر : بيانات عينة الدراسة الميدانية . 
1-القلق

تشير النتائج بالجدول (3) أن ما يقرب من ثلثى

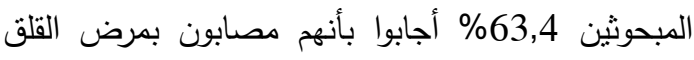

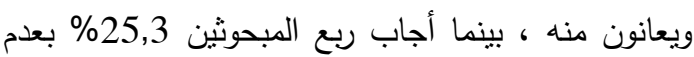

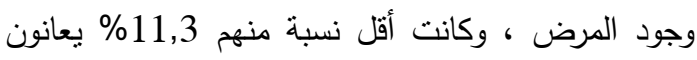

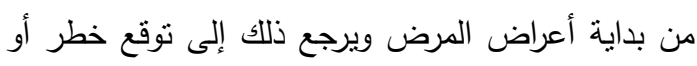
تهديد فعلى أو رمزى هو أنفعال يشعر به الفرد عندما يجد

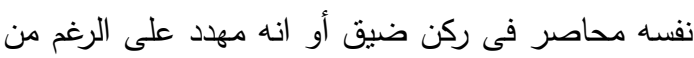

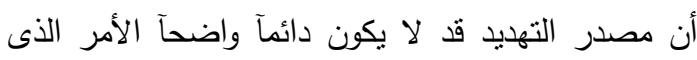

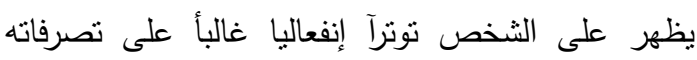

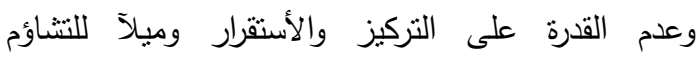
والأكتئاب والخوف دون سبب مما قد يؤدى إلى تغيرات

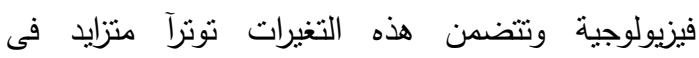
العضلات الخاصة بالهيكل العظمى وفى الجهاز القلبى

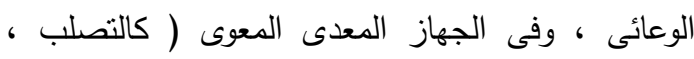
خفقان القلب بسرعة وقوة ،إسهال ) .

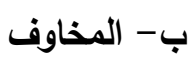

توضح النتائج بالجدول (3) أن ما يقرب من ثلثى

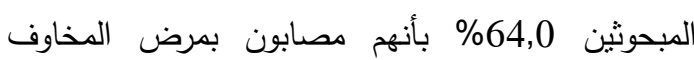
ويعانون منه ، بينما 20\% أجابوا بعدم وجود هذا المرض بأهن

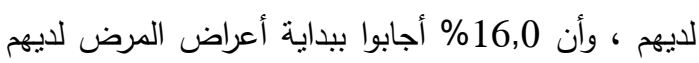

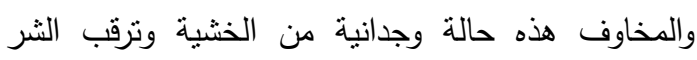
ترتبط بموقف أو موضوع بيئى معين وقد يكون الخوف عامآ غير محدد وهميآ كالخوف من الموت .
ثانيا : توزيع المبحوثين وفقآ لمستوى الرضا بسؤال المبحوثين عن الرضا عن النفس والمكان

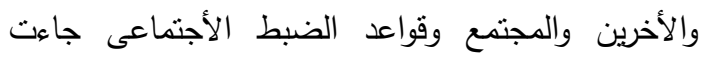
استجاباتهم على النحو التالى :

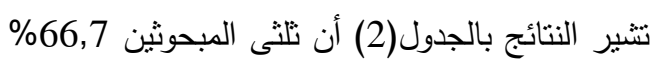

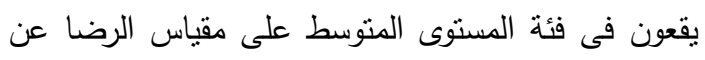

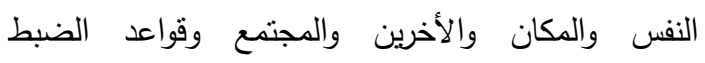
الاجتماعى ، وأن ما بزيد بقليل عن خمس المبحوثين

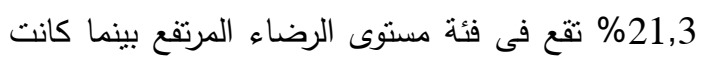

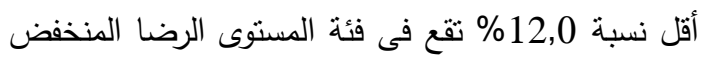

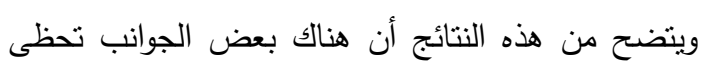

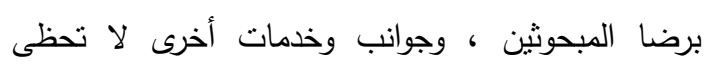

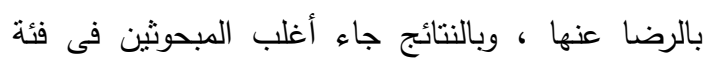

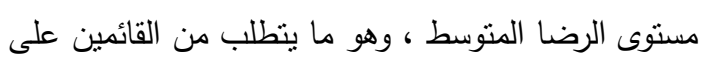

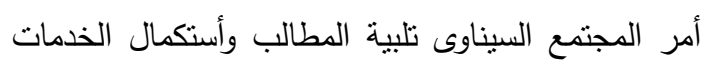

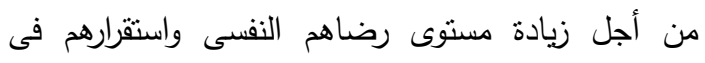

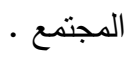

ثالثا: الأمراض النفسية التى يعانى منها الشباب

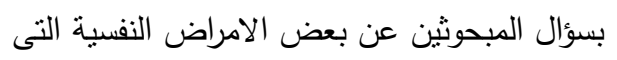

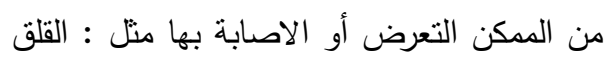

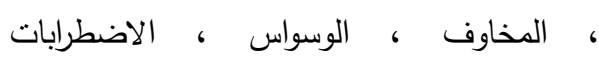

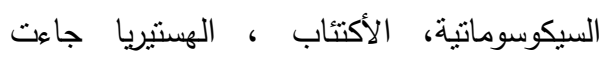

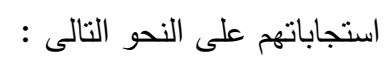

جدول ( 2 ) توزيع المبحوثين وفقآ لمستوى الرضا عن النفس والمكان والأخرين والمجتمع وقواعد الضبط الأجتماعى

\begin{tabular}{|c|c|c|c|}
\hline \multicolumn{2}{|c|}{ الرضاء عن النفس والمكان والأخرين والمجتمع وقواعد } & \multirow[t]{2}{*}{ المحاور } & \multirow[t]{2}{*}{ أستجابات الرضاء } \\
\hline$\%$ & 5 & & \\
\hline 12,0 & 18 & منخفض & \\
\hline 66,7 & 100 & متوسط & \\
\hline 21,3 & 32 & عالى & \\
\hline$\% 100$ & 150 & المجموع & \\
\hline
\end{tabular}

المصدر : بيانات عينة الدراسة الميدانية . 
جدول (3) توزيع المبحوثين وفقآ الأمراض النفسية التى يعانى منها الثباب

\begin{tabular}{|c|c|c|c|c|c|c|c|c|}
\hline \multicolumn{2}{|c|}{ الأجمالى } & \multicolumn{2}{|c|}{ موجود ويعانون منه } & \multicolumn{2}{|c|}{ بداية الأعراض } & \multicolumn{2}{|c|}{ لايوجد المرض } & حة التصو \\
\hline$\%$ & ك & $\%$ & كs & $\%$ & ك & $\%$ & ك & \\
\hline$\% 100$ & 150 & 63,4 & 95 & 11,3 & 17 & 25,3 & 38 & القلق \\
\hline$\% 100$ & 150 & 64,0 & 96 & 16,0 & 24 & 20,0 & 30 & المخاوف \\
\hline$\% 100$ & 150 & 44,7 & 67 & 37,3 & 56 & 18,0 & 27 & الوسواس \\
\hline$\% 100$ & 150 & 61,4 & 92 & 13,3 & 20 & 25,3 & 38 & السيكوسوماتي \\
\hline$\% 100$ & 150 & 75,3 & 113 & 16,7 & 25 & 8,0 & 12 & الأكتئاب \\
\hline$\% 100$ & 150 & 40,0 & 60 & 24,0 & 36 & 36,0 & 54 & الهستيريا \\
\hline
\end{tabular}

المصدر : بيانات عينة الدراسة الميدانية .

\section{د - الاضطرابات السيكوسوماتية}

توضح النتائج بالجدول(3) أن ما يزيد على ثلاثئة النهابه

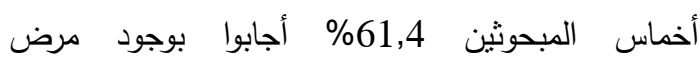

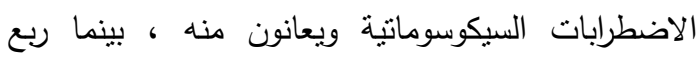
المبحوثين 25,3\% أحابوا بعدم وجود المرض وان 13,3 في بداية أعراض المرض عليهر

والاضطرابات السيكوسوماتية هى اضطراب جسى فى الظاهر تم فيه إخفاء الأضطراب الأنفعالى ( النفسى الإنى

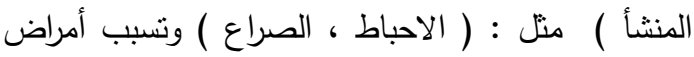
جسمية ( قرحة القولون ، الصداع النصفى ) ( ) الصاط ، الصرع ) وقد يرجع ذللك كله إلى الضغوط التى ينعرض لها الثخص فى تفاصيل حياته سواء داخل المنزل أو خارجه

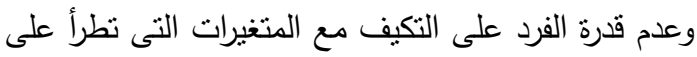
تحقيق أحتياجاته الأساسية مما يولد لديه صراعآ داخليآ

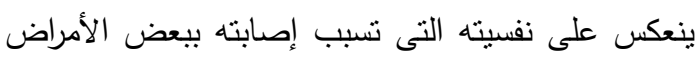

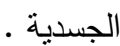

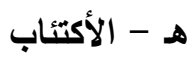

تبين من النتائج بالجدول (3) أن ما يزيد عن تلثى الاكي

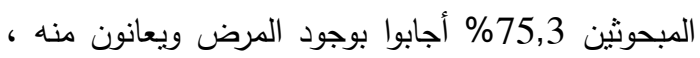
وان 16,7\% فى بداية أعراض المرض عليهح ، بينما

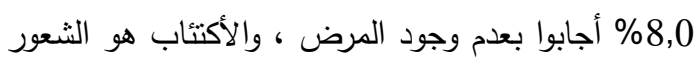
العميق بالفراغ والحزن وفى حالات كثيرة برافق الأكتئاب التعرد
أرجع هذا الخوف من الأعمال الإهاربية التى تقع على

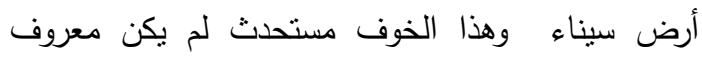
قديمآ، حيث بسيطر على أهل سيناء وقد وجدت هذه المخاوف لأسباب أختلاف العقائد أو الدذاهب وربط الدين بالسياسة ونسخير الدين لأغراض شخصية تهدف إلى بلوغ مراتب أو مكانة معينة مما يجعل الأنسان يفقد الأحساس بالأمن والطمانينة والهدوء ويتملكه حالات نفسية وجسدية ظاهرة على سلوكه وطبيعة تصرفه فهو يعرق ، يتتفس بصعوبة ، عدم الفدرة على التركيز . ج- (الوسواس تثير النتائج بالجدول(3) أن 44,7\% من المبحوثين لديهر مرض الوسواس ويعانون منه ، بينما 37,3\% أجابوا ببداية أعراض المرض لديهم فى حين يرى 18,0\% منهم بعدم وجود هذا المرض لديهم العرصن ويرجع ذلك إلى ما يسببه القلق من أفكار وهى عبارة عن (هواجس) سلوكية متكررة تراود الإنسان سواء فى الفى صحيانه أو نومه إلى الحد التى تمثل خطورة على على حياته فتروده أفكار يغلب عليها الثك والتزدد ، وقد يؤدى إصابة الفرد بهذا المرض إلى أصابته بمرض الأكتئاب وقد يرجع سبب الاصابة بهذا المرض هو نتيجة

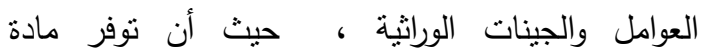

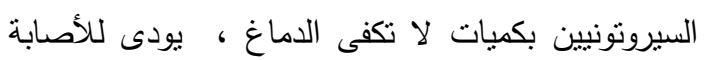

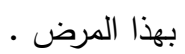


رابعاً: العلاقة بين أبعاد مقياس التصحر والرضا

\section{عن المجتمع}

- لاختبار معنوية العلاقة بين أبعاد مقياس التصحر

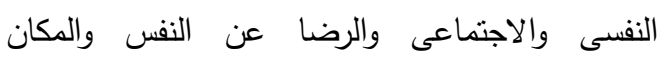

والأخرين والمجتمع وقواعد الضبط الأجتماعى ، تم والنماعن

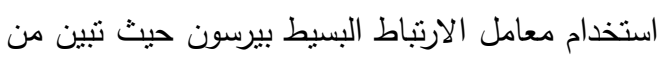

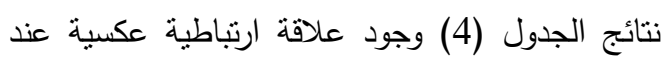

مستوى معنوية،05، وبين الرضاء عن المجنمع وبين

كل من القلق ، والأكتئاب وبلغت قيمة معامل الارتباط الرضاه

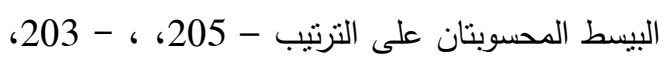

وهى اكبر من نظيرتها الجدولية ، وهو ما يعنى أنه النه

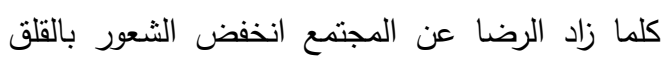

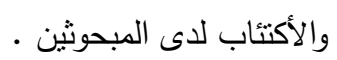

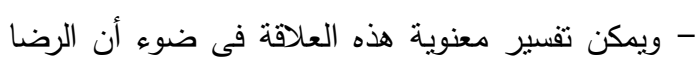

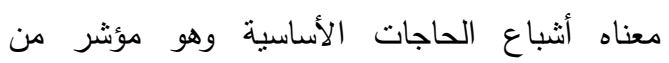

مؤشرات السعادة ويغطى مجالات متعدة فى حياة الفرد

منها الصحة الجسمية والنفسية والاجتماعية والروحية والاخلاقية ويعنى تقبل الحياة فى هذا المجتمع مهما

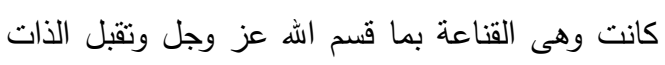
والاخرين بالعفو والتسامح وبالتالى يقل نوتره وإصابته

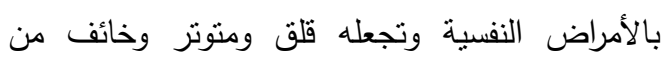

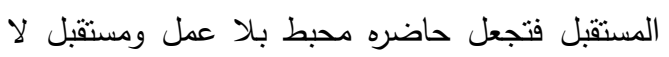

يعلمه إلا اله .
بعض المؤشرات الجسمانية مثل الام فى الظهر وارهاق

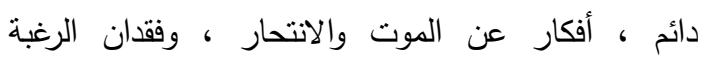

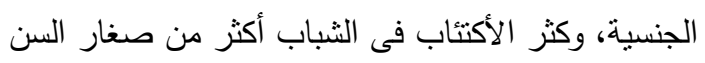

$$
\text { والمسنين }
$$

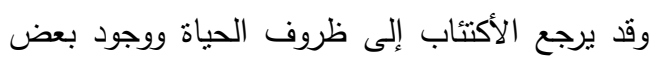

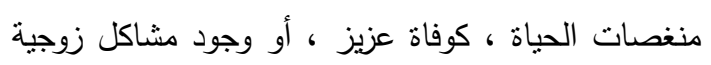
وأسرية ، وفقدان العمل ، وتدهور الصحة ، ولئه ، المشاكل

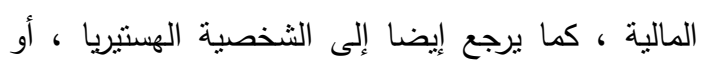

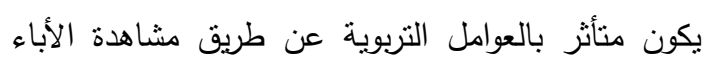
بأنماط معينة من السلوك منل ( التشاؤم والأكتئاب وأساة الظن والحساسية المفرطة ) مينة السلوك مئل

$$
\text { و - الهستيريا }
$$

أشنارت النتائج بالجدول (3) أن 40\% أجابوا بأنهم

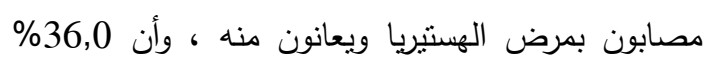

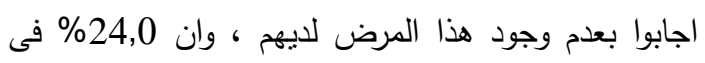

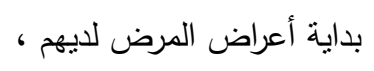

ويرجع الأصابة بالمرض إلى الصراع لائه بين الغرائز

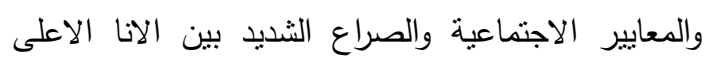

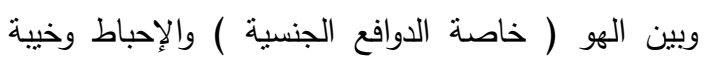
الأمل فى تحقيق هدف أو مطلب والفشل والحرمان ،

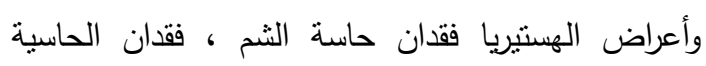

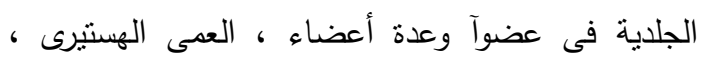

\begin{tabular}{|c|c|}
\hline قيم معامل الارتاط البسيط & أبعاد المقياس \\
\hline$*, 205-$ & القلق الق \\
\hline ,093 & المخاوف \\
\hline ,039- & الوسواس \\
\hline , 136 & الأضطرابات السيكوسوماتية \\
\hline$*, 203-$ & الأكتئاب \\
\hline ,062 & الهيتيريا \\
\hline
\end{tabular}
الصمم الهستيرى .

جدول ( 4 ): قيم معامل الارتباط البسيط بين أبعاد مقياس التصحر والرضا عن المجتمع

المصدر : بيانات عينة الدراسة الميدانية . 
التالى وفقآ للمنوسط المرجح جدول رقم (6) حيث جاء فى كري

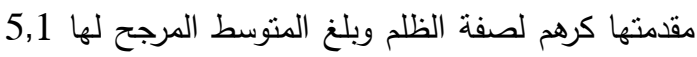
درجة من ست درجات ، وتلى ذلك كرهم لصفة الخيانة

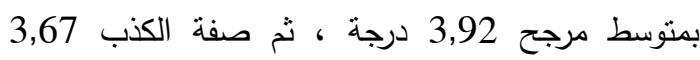
درجة، ثم صفة عدم الإيمان 3,0 درجة ثم صفة سؤ دأ

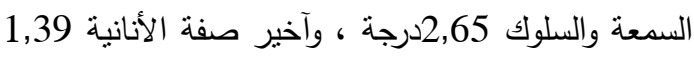
درجة ، وعلى هذا يتضح أن معظم الصفات غيرالاخلاقية الانية

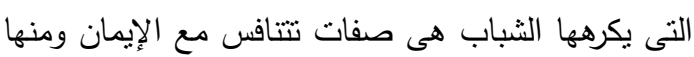

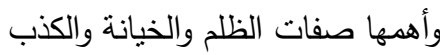
ونلاحظ أن الثباب السيناوى بعيش حالة من حالات التصحر النفسى والاجتماعى تتفاوت فى حدتها بين الأولية والبسيطة والثديده

سابعاً: الخدمات التى يحتاجها المبحوثون بسؤال المبحوثين عن الخدمات التعليمية والاجتماعية

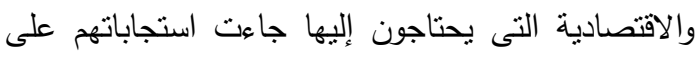
: النحو التالى

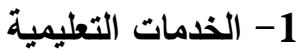

تبين من النتائج بالجدول(7) أن غالبية المبحوثين 80 أجابوا بحاجة المنطقة إلى كل الخدمات التعليمية من دور الحضانة ، والمدارس الابتدائية والاعدادية

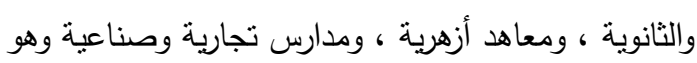

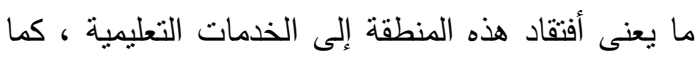

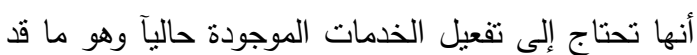

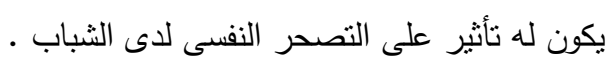

خامساً: التعرف على الصفات الأخلاقية المتأصلة لاى الثباب

تضمنت الصفات الأخلاقية المدروسة ست صفات هى: العدل ، والسمعة الطيبة ، والأمانة ، والصدق الصنه ،

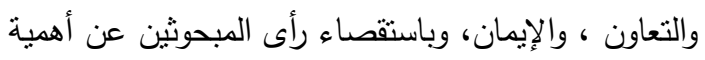
هذه الصفات ، تبين من النتائج جدول (5) أن هذه الصفات جاءت مرتبة نتازليا وفقا للمتوسط المرجح على النحو التالى حيث جاء فى مقدمتها ، صفة الإيمان وبلغ المتوسط المرجح لها 4,35 درجة من ست درجات وهو ما هاء يعكس تدين المجتمع البدوى نظرآ للموروث الثقافى الذى بعطى للدين أهمية كبيرة فى حياتهم ، ثم صفة الامانة بمتوسط مرجح 4,9 درجة ، وهى مرتبطة بصفة الإيمان ، وتلى ذلك صفة الصدق بمتوسط مرجح 4,0 درجات ، قسم صفة العدل بمتوسط 3,83 درجة ، ثم السمعة الطيبة 3,0 درجة وأخيرآ صفة التعاون 2,62 درجة ، ويتضح من هذه النتائج أن صفة الإيمان وما يتبعها من صفات نابعة منها منل الصدق والأمانة والعدل هى صفات أخلاقية منأصلة

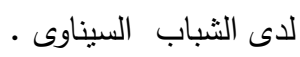

سادساً: الصفات غير الاخلاقية اتى لا يفضلها

\section{الشباب ويكرهونها}

تضمنت الصفات غير الاخلاقية المدروسة سبب

صفات هى الظلم ، سوء السمعة والسلوك ، الخيانة ، الأنانية ، الكذب ، عدم الإيمان ، وباستقصاء رأى

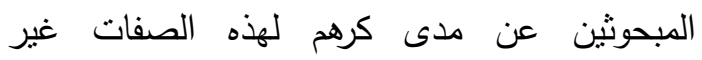
الاخلاقية جاءت استجاباتهم مرنبة تنازليا على النحو

جدول ( 5 ) : توزيع المبحوثين وفقا للاهمية النسبية لصفات الاخلاقية

\begin{tabular}{|c|c|}
\hline المتوسط المرجح & الصفات الاخلاقية \\
\hline 4,9 & الامانة \\
\hline 4,35 & الإيمان \\
\hline 4,0 & الصدق \\
\hline 3,83 & العدل \\
\hline 3,0 & السمعة الطيبة \\
\hline 2,62 & التعاون \\
\hline
\end{tabular}

المصدر : بيانات عينة الدراسة الميدانية . 
جدول رقم ( 6 ) توزيع المبحوثين وفقا لإستجابتهم عن مدى كرهم للصفات غير الاخلاقية

\begin{tabular}{|c|c|}
\hline المتوسط المرجح & الصفات غير الاخلاقية \\
\hline 5,1 & الظلم \\
\hline 3,92 & الخيانة \\
\hline 3,67 & 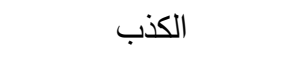 \\
\hline 3,01 & عدم الإيمان \\
\hline 2,65 & سؤ السمعة والسلوك \\
\hline 1,39 & الانانية \\
\hline
\end{tabular}

جدول ( 7 ) توزيع المبحوثين وفقآ للذدمات التعليمية التى تحتاجها المنطقة

\begin{tabular}{|c|c|c|}
\hline$\%$ & ك & الخدمات التعليمية التى يحتاجها المكان \\
\hline 20,0 & 30 & دار حضانة \\
\hline- & - & مدرسة إبتدائى \\
\hline- & - & مدرسة إعدادى \\
\hline- & - & مدرسة ثانوى \\
\hline 80,0 & 120 & كل ما سبق \\
\hline$\% 100$ & 150 & المجموع \\
\hline
\end{tabular}

المصدر : بيانات عينة الدراسة الميدانية .

الخدمات ، بينما أجابا 23,3\% منهم بالحاجة إلى مركز شباب ، 2,7\% بدون حاجة المنطقة إلى وحدة اجتماعية . 4- - - 2 - الغدمات الإقتصادية تشير البيانات الواردة بالجدول(10) أن أكثر من تلث

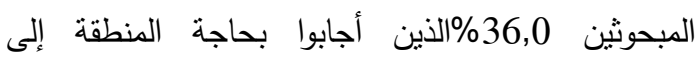

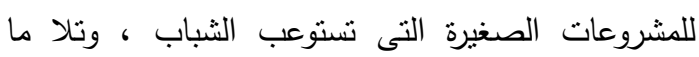

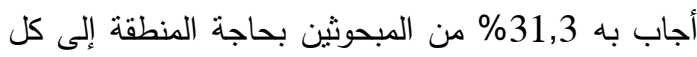

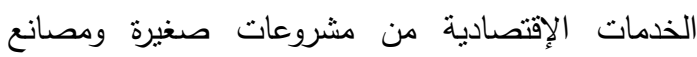
وجمعية استهلاكية ، فيما برى اقل من ربع العينة 21,3

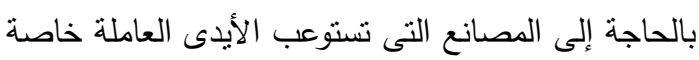

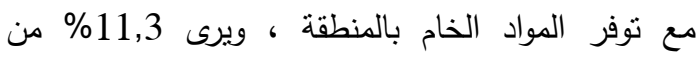
المبحوثين ان المنطقة بحاجة الى جمعية استلاكية ، وعليه

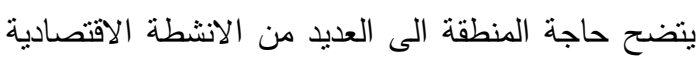

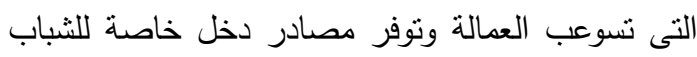

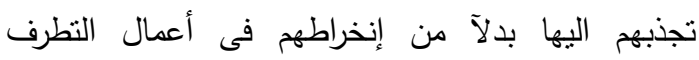

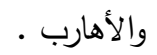

2- 2- الغدمات الصحية تثير البيانات الواردة بالجدول (8) أن أعلى نسبة

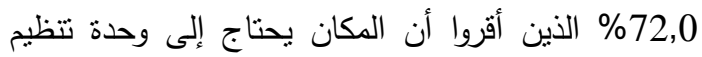

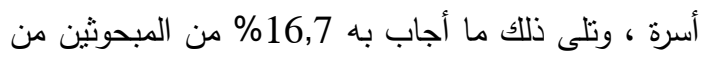

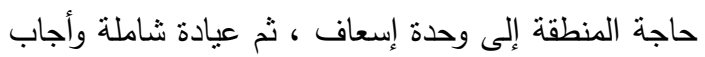
بذلك 6,0\% ، وأخيرآ أجاب 5,3\% من المبحوثين بحاجة المنطقة إلى كل ما سبق وحة إسعاف ، عيادة شاملة ، وحدة تنظيم أسرة . 3- الخدمات الاجتماعية والثقافية

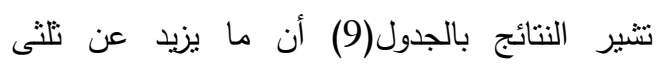
المبحوثين 68,7\% أجابوا بحاجة المنطقة إلى كل بلى الخدمات الاجتماعية والثقافية من وحدة اجتماعية ، ومركز

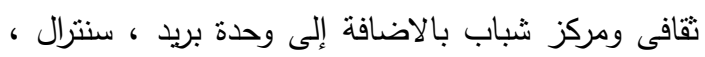

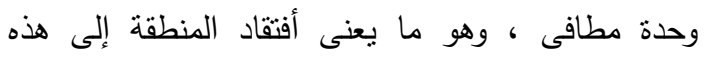


جدول (8): توزيع المبحوثين وفقآ للخدمات الصحية التى تحتاجها المنطقة

\begin{tabular}{|c|c|c|}
\hline$\%$ & ك & الخدمات التعليمية التى يحتاجها المكان \\
\hline 16,7 & 25 & وحدة إسعاف \\
\hline 6,0 & 9 & عيادة شاملة \\
\hline 72,0 & 108 & وحدة تتظيم الأسرة \\
\hline 5,3 & 8 & كل ما سبق \\
\hline$\% 100$ & 150 & المجموع \\
\hline
\end{tabular}

المصدر : بيانات عينة الدراسة الميدانية .

جدول ( 9 ) توزيع المبحوثين وفقآ للذامات الاجتماعية والثقافية التى تحتاجها المنطقة

\begin{tabular}{|c|c|c|}
\hline$\%$ & ك & الخذمات الاجتماعية والثقافية التى يحتاجها المكان \\
\hline 2,7 & 4 & وحدة اجتماعية \\
\hline 23,3 & 35 & مركز ثقافى \\
\hline 5,3 & 8 & مركز شباب \\
\hline 68,7 & 103 & كل ما سبق \\
\hline$\% 100$ & 150 & 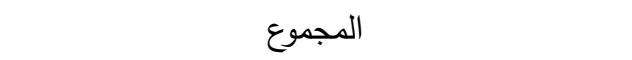 \\
\hline
\end{tabular}

المصدر : بيانات عينة الدراسة الميدانية .

جدول ( 10 ) توزيع المبحوثين وفقآ للذدمات الإقتصادية التى تحتاجها المنطقة

\begin{tabular}{|c|c|c|}
\hline$\%$ & ك & الخدمات الاقتصادية التى يحتاجها المكان \\
\hline 36,0 & 54 & مشروعات صغيرة \\
\hline 21,3 & 32 & مصانع \\
\hline 11,3 & 17 & جمعية استهلاكية \\
\hline 31,3 & 47 & كل ما سبق \\
\hline$\% 100$ & 150 & المجموع \\
\hline
\end{tabular}

المصدر : بيانات عينة الدراسة الميدانية .

مصادر التمويل لهم وتسهيل إجراءات حصولهم عليها وكنللك إقامة هذه المشروعات الإنتاجية ، فيما يرى

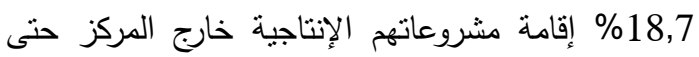

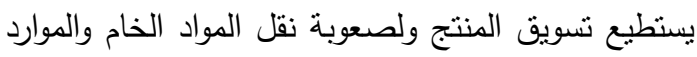
الطبيعية إلى المركز ولحماية المركز من مخلفات المشروع.
تبين من الجدول (11) أن ما بزيد على أربعة أخماس

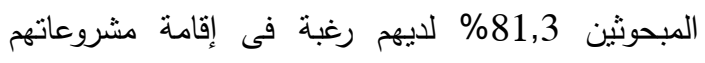

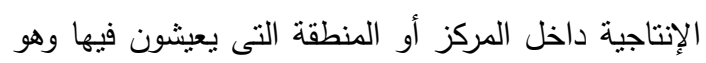
ما يعكس إنتمائهم القوى نحو الارض والرغن الرغبة فى تنمية

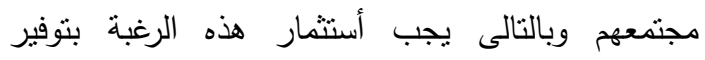


جدول (11): توزيع المبحوثين وفقآ للمكان المقضل لأقامة مشروع صغير

\begin{tabular}{|c|c|c|}
\hline$\%$ & ك5 & المكان المفضل \\
\hline 81,3 & 122 & داخل المركز \\
\hline 18,7 & 28 & خارج المركز \\
\hline$\% 100$ & 150 & المجموع \\
\hline
\end{tabular}

المصدر : بيانات عينة الدراسة الميدانية .

وهذه السمات الثخصية لا تكثف عن نفسه فى أى وقت بل يكثف عن نفسه فحسب فى المواقف النفسية المعقدة التى نولد ضغطآ يتقل على ( الحلقة الضعيفة ) كما أسفر البحث أن هناك مجموعة من ضغوط الحياة

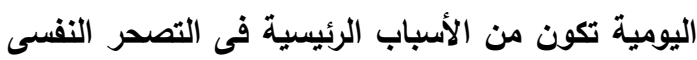
والاجتماعى نقسمها على النحو التالى : 1- ضغوط فى محيط الأسرة

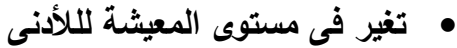

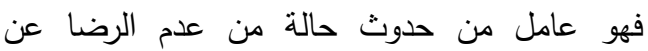
المعيشة فى عمومها

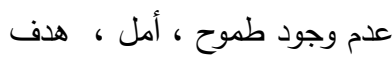
يجعل الثاب يعيش ومن حوله قيم الثشاؤم والفنل والإحباط وعدم الأمل والياس من الحياة أفتقاد معنى

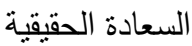
فدائعاً الثباب فى حالة شجار وتوتر وعدم إنسجام فيعيش جميعا حالة من عدم السعادة بختلاف درجاتها واتئان النسبية

\section{• الضعف الجنسى أو الفتور الجنسى}

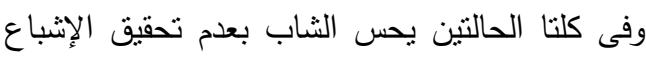
الجنسى الذى يمثل حاجة أساسية من حاجات الإنسان ، لإنساع وهذا ما يجعل الثاب يصاحب بحالة من عدم الأنسجام والرضاء عن النفس ولن تغير فى ظروف المسكن فى حالة انهيار المبانى وانتقال العديد من الأسر للسكن فى مساكن الايواء أو المساكن الثعبية والتخلى عن

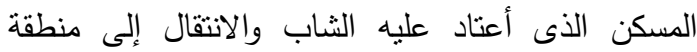

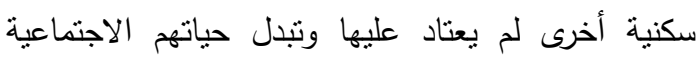

ثامنآ : الخلاصة والتوصيات أصبح الثباب السيناوى يعيش حالة من الأكتئاب

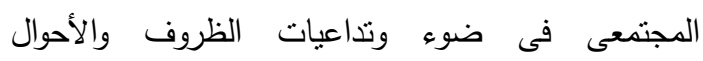

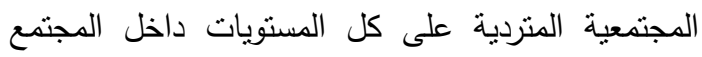
السيناوى ولما يحدث على كافة الأصعدة والمستويات من العن إهدار لأبسط حقوق وكرامة الإنسان مما يصيبه بحالة من الاستياء والإحباط والإخفاق. من أهم النتائج التى توصل إليها البحث فى ضؤ

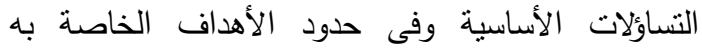
والاساليب البحثية التى أعتمد عليها لتحقيق الأهداف. ومن اهم السمات السمات الثخصية للإفراد الذين يعانون من التصحر النفسي والاجتماعي : - تباين فى المزاج النفسى نتيجة لموقف خارجى ـ ل - القلق ، التردد، الإرهاق ، سرعة الإستتارة ، الميل

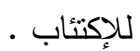

- - الخجل ، الحساسية ، الميل للشعور بالدونية.

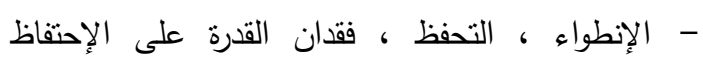
بالصلات الثخصبة ، فقان القدرة على التعاطف . - السلوك غير المحكم والمندفع ، التعصب ، التصلب

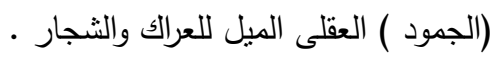

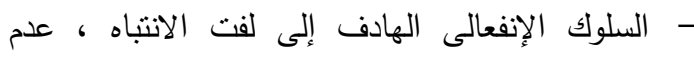

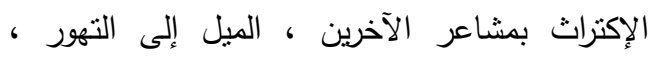

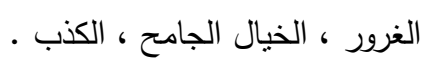

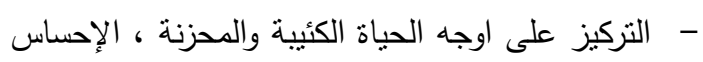
الزائد بالمسئولية . 
وبالتالى نسؤ حالة الثاب النفسية تدريجياً ويمر بالمراحل

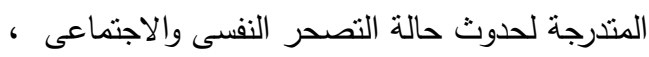

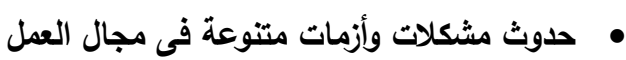

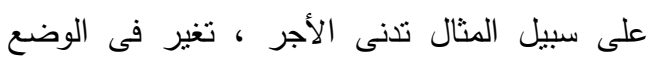

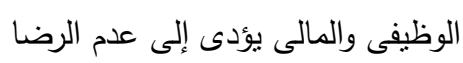
الفشل فى أكتساب الخبرات

يجعل الثاب يشعر بالفشل والإحباط وتزداد حالته النفسية والاجتماعية سوءا ليجاب لئرل

\section{3- ضغوط فى محيط الحياة العامة}

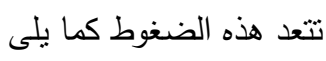

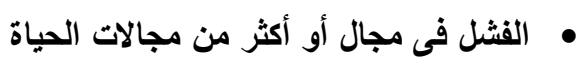

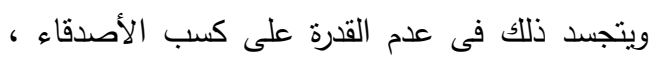
الفشل فى العلاقات الغرامية ، عدم القدرة على الحوار والتفاعل الإيجابى في

• بت الرغبات الجنسية للثباب غير المتزوجين

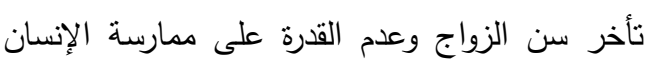
لحقوق الجنسن فى صورتها الثرعية قد يسبب له آلآما

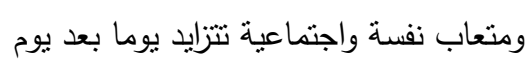

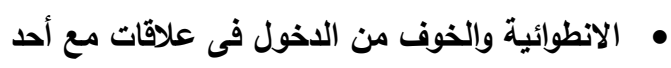
وتتجس ذلك فى الاحساس بالوحده وعدم الرغبة فى الحياة

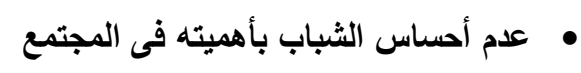

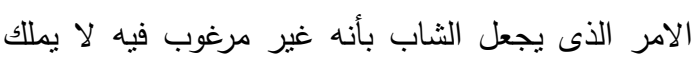

$$
\text { التأثير فى المحيطين }
$$

\section{• الإحساس بصعوية الحياة بصفة عامة فين}

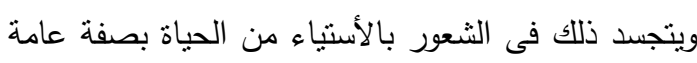
ونتيجة تفشى الفساد والمحسوبية ، الإحساس بالإحباط

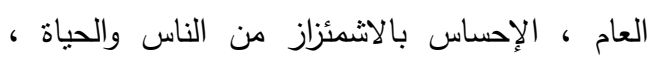
الإحساس بالفشل ، عدم الرضا عن النفس وعن

$$
\text { المجنمع }
$$

$$
\text { • الخوف من المستقبل }
$$

شعور الثاب أن مستقبله غبر مأمون مما يودى إلى زيادة التوتر والعصبية والقلق

\section{• صعوية الحياة ماديا واجتماعياً ونفسيا}

عدم قدرة الثباب على مواجهة منطلبات الحياة مئليات
ينعكس ذلك بالسلب على صحتهم النفسية وعدم الرضا عن الحياة بصفة عامة • عدم الرضا وندب الحظ

يؤدى إلى شعوره بالحقد والحسد على الآخرين وعدم الحما

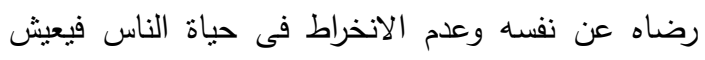

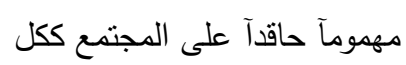

$$
\text { • الفراغ والفتور الدينى }
$$

يشكل عاملآ نفسيا فى اعتلال الصحة النفسية للثباب

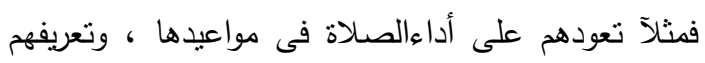

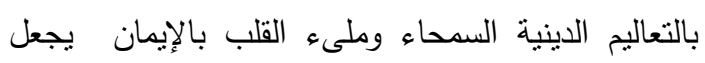

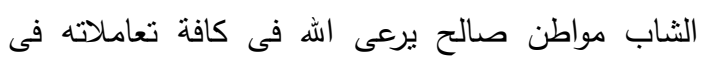
المجتمع • افتقاد لغة الحوار البناء على مستوى الأسرة والمجتمع

فينشأ الثاب غير قادر على إدارة كافة أموره بشكل عدم القدرة على ممارسة الأنشطة الترفيهية

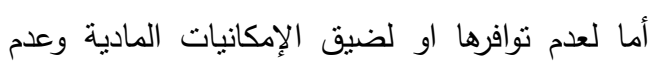

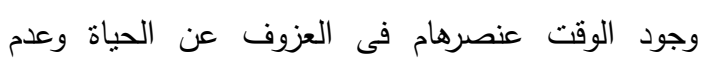

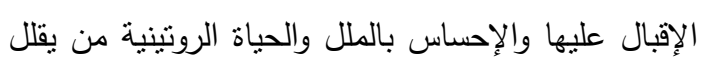
من عنصر البهجة والسعادة فى الحياة. 2- ضغوط فى محيط العمل تتنتل أهم هذه الضغوط فيما يلى فيط لعيل

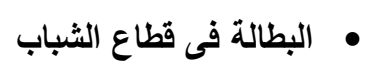

تمثل عامل هام فى حدوث عدم النوازن النفسى وهذا برجع لعدم استطاعة الثاب بأداء اي عمل برفع من مكانته

$$
\text { ويحسسه بأهمية وجوده ودوره فى الحياة }
$$

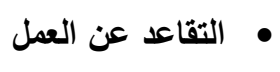
سواء كان التقاعد مبكرآ أو لعدم القدرة على إيجاد عمل العل

$$
\text { • أو الفصل من الأصابة من العمل }
$$

يؤدى إلى حدوث تبادل فى حياة الثناب وحدوث

انخفاض فى مستوى المعيثة نتيجة افتقاد الفرد لمرنبه 
تحسين أحواله وتحديد هدف لله بسعى لتحقيقه دون الإضرار بحقوق الآخر • الأنكسار وعدم الثجاعة فى مواجهة الآخر وسيادة الآنر مشاعر القوة والعنف والتسلطبة من جانب الأقوى على القى الضعيف • سيادة مشاعر الاحباط بين معظم الثباب السيناوى

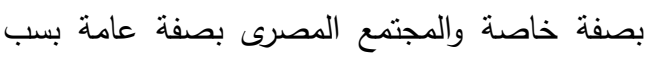
العديد من الشكلات والتحديات التى يواجهوانها لمواجهة منطلبات الحياة من حيث الضرورات وليس الكماليات فى المجتمعات ذات الدخول المتننية ولهذا أصبح من المعتاد أن تسمع انا يائس أنا قلق ناهيك الكئك

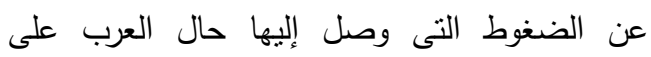

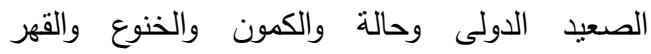
والرضوخ والانصياع التى أصبحت تتحلى بها القيادت ولهن أو الزعامات العربية فى ت تعاملها مع القوى الغربية

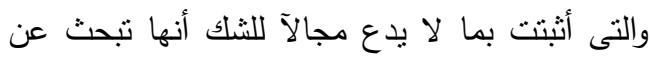

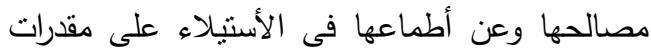

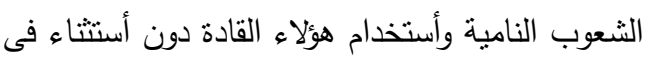

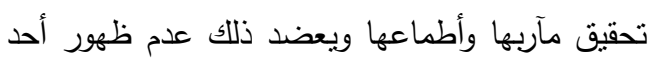
من بين تللك الزعامات يعيد العزة والكرامة والبهجة

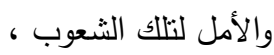

بناء عليه أصبح الثباب السيناوى بصفة خاصة والثباب العربى بصفة عامة غير آمن على نفسه وتتجسد

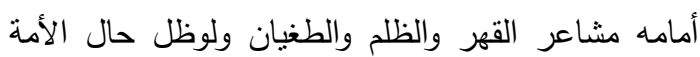
العربية هكذا من الانعزال والفرقة والتمزق وعدم توحد ولمدان الوجدان العربى والعقل العربى والمشاعر القومية العربية من الممكن حدوث ما هو أكثر من ذلك ـ وجود هوه نقافية

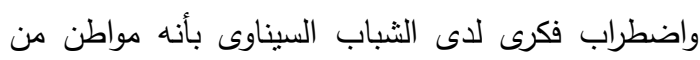

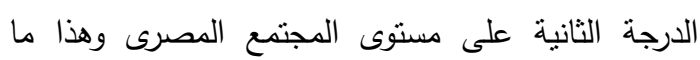
جطهم يشعرون بالحزن والأكتئاب . وعدم توافر فرص النجاح وتحقيق الآمال أو جود بأرقة

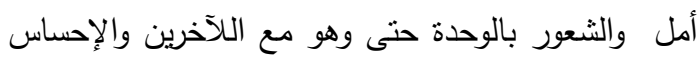

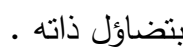
• إنخافض مستوى الطموح وأصبح بعيدآ عن الواقع وصعوبة تحقيقه للطبقات الفقيرة والمنوسطة حتى لو
وحاجاته ورغباته الاساسية مما يصييه بمشاعر الإحساس بالفشل واليأس والإحباط • زيادة العنف على المستوى المجتمعى والاهياه

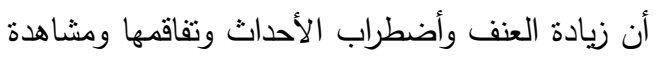
الصور والمناظر الانتهاكية لحقوق الإنسان والقهر والظلم

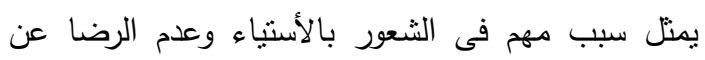
الحياة برمتها

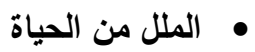
يمثل أصعب المواقف وأن الحياة لبس لها قيمة عنده وقد يتمنى البعض الموت وإنها حياته

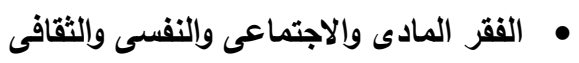
سبيآ هامآ فى حدوث عزوف الثباب من الحياة والفي الفياف العامة لأنه لا يستطيع مواجهة متطلبات حياته ويحس بالعجزعن تحقيق أى إنجاز لقصورإماكانياته

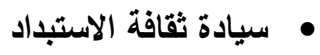

الاب والام مستبدان ومساحة الحرية ضئيلة ثم الرئيس الاسئال فى العمل وبهذا تأصلت فينا مشاعرهذه الثقافة بالرضوخ والاستكانة وبالتالى تغتال الحرية وتؤدى فى النهاية إلى لى

$$
\begin{aligned}
& \text { عدم التوازن النفسى والاجتماعى لإلى لإنى } \\
& \text { • الفتور الاجتماعى لـؤل }
\end{aligned}
$$

ويتمنل فى عزلة الثناب وإنطوائه على ذاته ويعيش الاجئ حالة اغترابية فى داره وفى مجتمعه وبالتالى لا يشبع

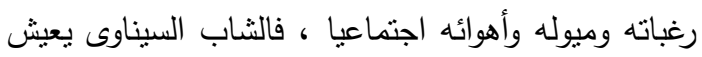
حالة من الحضن الاجتماعى المفقود

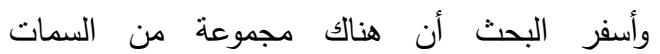
الثخصية للأفراد الذين يعانون من التصحر النفسى

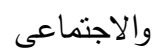

عدم إحساس الثباب بالحرية النفسية وأصبح العديد من الثباب يذهب إلى أنه أسيرهمومه وأحزانه وأحلامه

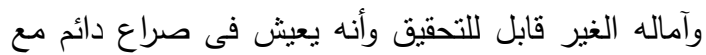
نفسه ومن هذا المنطلق فهو يتصرف بلا وعى وبلا إدراك وبتهور فى كافة أمور حياته

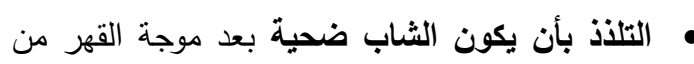
الخارج ومن الداخل ، وعدم تفعيل الطاقات الكامنة داخل الثباب للتغلب على ظروفه ومحاولته دائماً 
إحساس الثباب بأهمية دوره أو ما هو المطلوب منه

$$
\text { من أجل تقدم مجتمعه }
$$

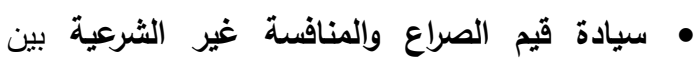

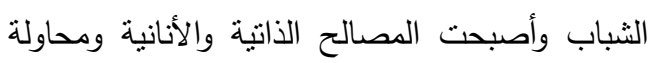

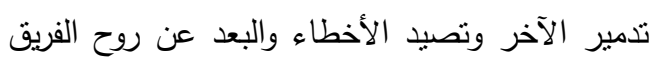
والعمل الجامعى وتأكيد قيم الأعتزاز بالوطن والأنتماء.

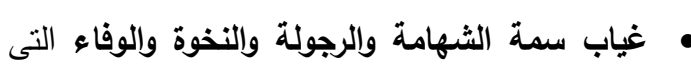
كانت سائدة وظهور سمات ومشاعر التبجح وعدم

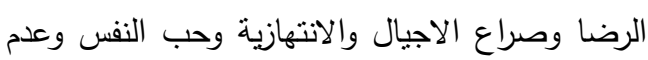

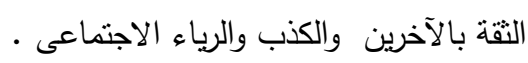
• افتقاد لغة الحوار والتقاهم والتراحم والمودة داخل

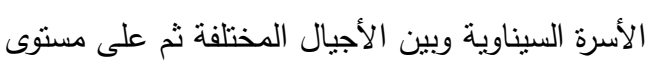
الجامعة بين جيل الاساتذة والتلامذة وهذا أدى إلى الى الى الى سيادة مشاعر الكراهية والعنف والتهور وعدم التفاعل الأيجابى وزيادة مشاعر السلبية وعدم الاكتراث والاحترام المتبادل بين الاجيال المختلفة فكريا وعمرياً . • سرعة الأستثارة والغضب لاى الثباب ننتجة زيادة لإل

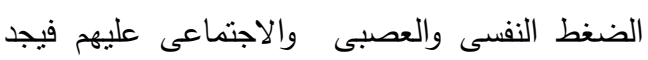
الثناب نفسه أمام أقوال الوالدين المتضاربة ومشاعر

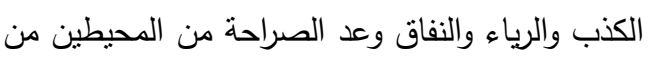

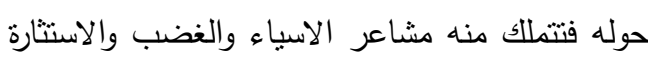

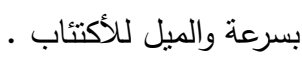
• الثعور بالخمول والكسل وعدم القدرة على الأداء للاءلَ الحركى لأى أنشطة • الثكوى المستمرة من الآلام العضوية وعدم القدرة على الحركة وسرعة التعب والإرهاق

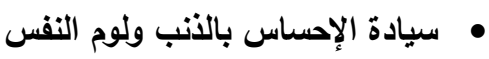
• سيادة أنماط التفكير الإنهزامى وعدم الإدراك الجيد النيان

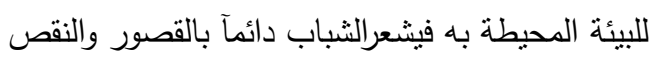

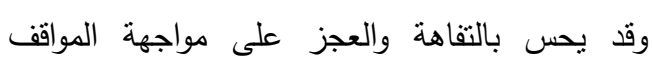

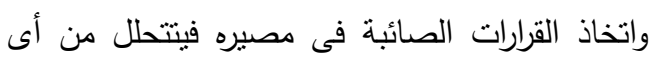

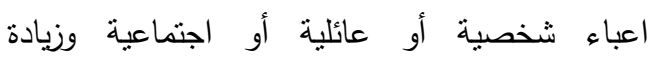
الإحساس من جانب الثخص بضآلة ذاته وعدم رضاه
تحقق حلم الثباب بالتخرج بتفوق وبتميز فلا يجد عمل يتناسب مع مؤهله أو حتى أى عمل عادى وتبدأ رحلة

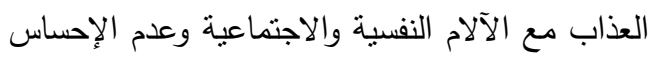

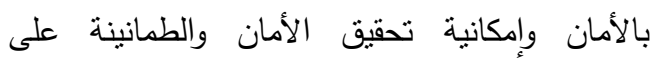
المستقبل ، وييدأ فى الإحساس بأن حياته خدعة وأنه

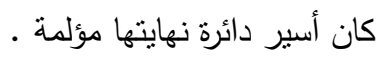

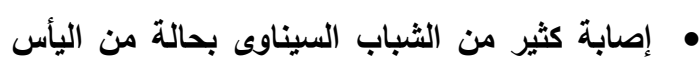

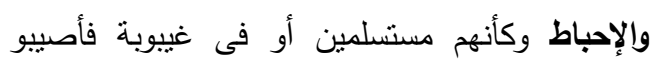
باستكانه نتيجة إنتشار الفساد والرشوة والماطئ والمسوبية واستغلال النفوذ والسلطة والمتأجرة بقيم الثرف وخدمة النّاد

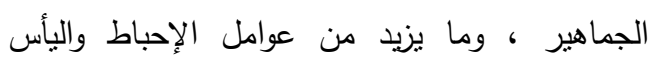

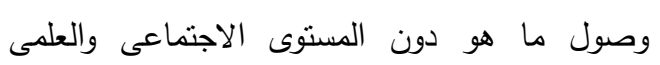
والأخلاقى إلى المركز الكبرى هم وذويهم وما يجرى دوى الأثاعى والعلى

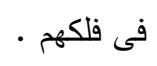
• زيادة مشاعر الملل وروتينية الحياة وعدم التغير

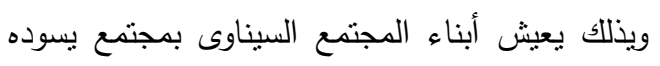

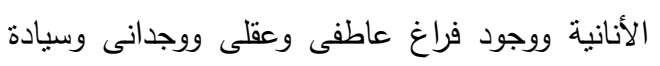

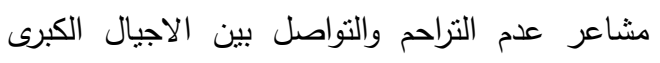

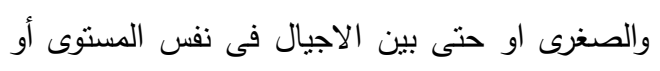

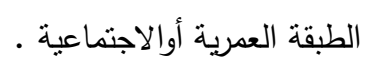
• افنقاد المعنى الحقيقة للحياة خاصة فى خلى خطاعل الثباب من الجنسين وذلك بسبب حدة البطالة وتأخر

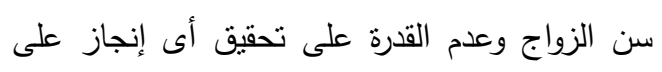

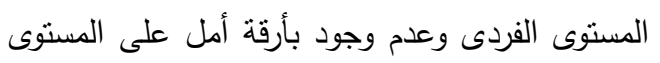

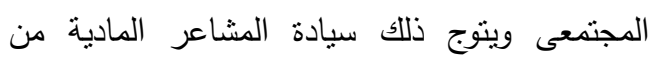

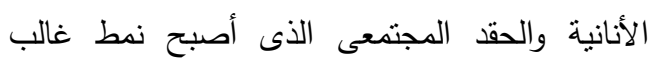
والبعد عن المشاعر العاطفية والمشاعر الإنسانية • مشاعر الذوف والقلق من المستقبل التى بدأت نتملك الكئل

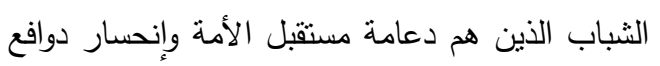
الإنجاز وبالتالى ضعف القدرة على المثابرة والجد والصمود والإصرار سيادة مشاعر السلبية واللامبالاة والانتهازية والتواكلية كنمط غالب للشخصية الثباب السيناوى بصفة خاصة والثخصية المصرية بصفة عامة وهذه نتيجة عدم 
وهذا دور التربية الحديثة فهى تهتم بالفرد ككل وتهيىء الفرص لإثباع حاجاته البيولوجية ولنمو حاجاته ككائن بيولوجى وحاجاته النفسية والإجتماعية ككائن أجتماعى لإنى كائه وتساعده على التقام والنمو وأنها تهتم بالرعاية العقلية لنساعد الفردعلى النمو الثامل لثخصية للقيام بأدواره

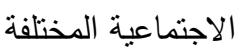

التربية : عملية أجتماعية لأنها تنعى لتحقيق التكيف بين الفرد والدجتمع وتمكن الفرد من المعيشة مع بقية أعضاء المتمع وتكوين علاقات أجنماعية مناسبة معهم والمشاركة فى تفديم الحياة المعيشية فى المجالات المختلفة، ومن أهم الهيئات التى تلعب دور فى أعادة التوازن النفسى والاجتماعى الأسرة والمدرسة

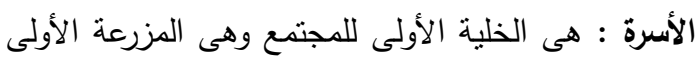

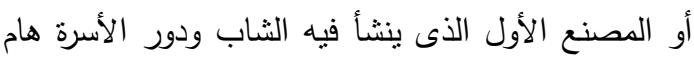

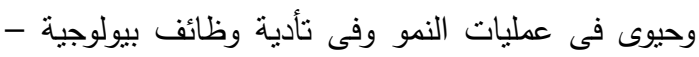
اجتماعية - نفسية

للأسرة دور هام فى إثباع حاجة الثباب بصفة خاصة والإنسان بصفة عامة إلى التقدير الإجتماعى وللثاب فى إلى التياب الأسرة أن يعبر عن ذاته ومشاعره وأحساسيه وعدم تقييد

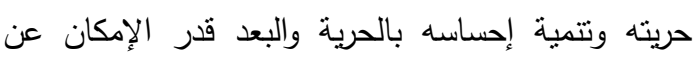

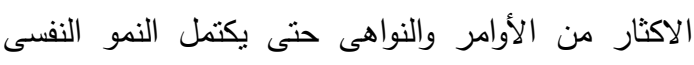

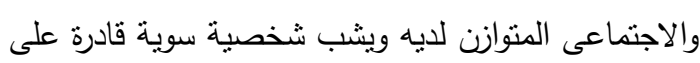

التعامل مع المواقف المختلفة فى حياته بثقة وتعقل .

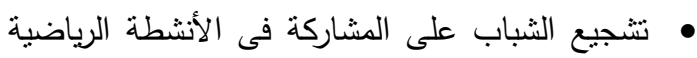
والثقافية المشاركة الفعالة التى تعزز وتدعم بناء الفياء الثحصية القوية .

• ت تشيجع الثباب على ان يكون لهم رؤية فى المستقبل وتعليمهم أنماط سلوكية تجعلهم يتعلمون الأستخدام

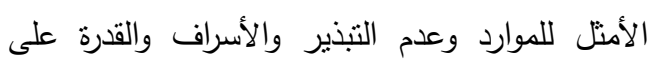
ترشيد الاستهلاك للموارد فى المستقبل . • حس الثباب على اتباع التعاليم الدينية الصحيحة

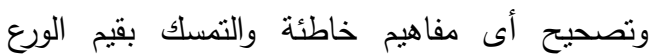
والثقوى وعدم إقتراف أى سلوك أو فعل فاحش .
• وجود علاقة إرتباطية معنوية عكسية بين الرضا عن

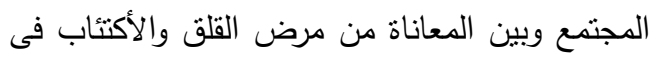

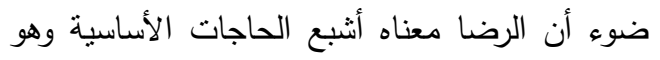

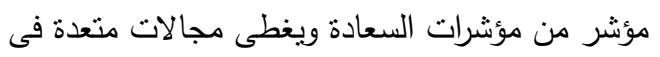

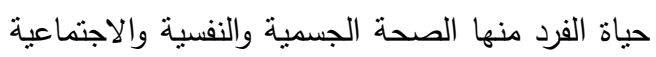

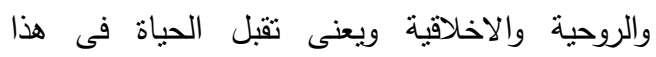
المجتمع مهما كانت وهى القناعة بما قسم الله عز ولئي

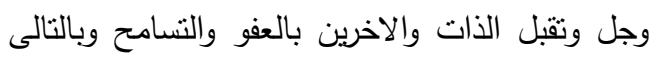

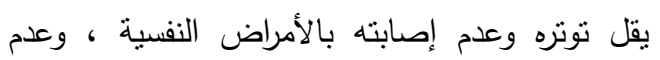

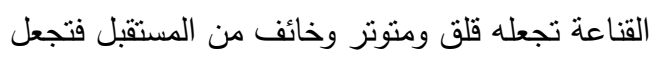
حاضره محبط بلا عمل ومستقبل لا يعلمه إلا اله .

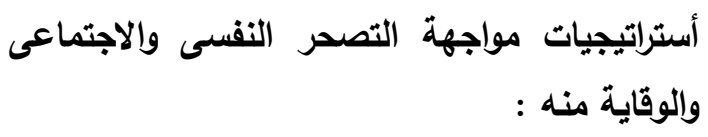
تنطلب مواجهة التصحر النفسى والاجتماعى والوقاية منه مسئولية جماعية لابد أن تتكاتف العديد من الهيئات

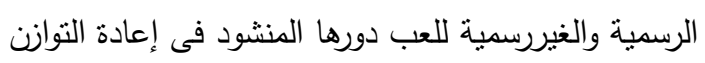

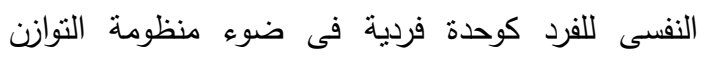
النفسى الاجتماعى للمجتمع ككل

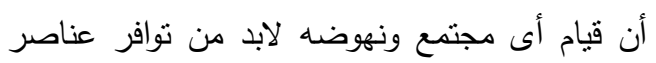
ثلاثة : الأفراد ، الثقافة المشتركة ، المكان المجتمع : عبارة عن مجموعة من الأفراد تجمعهم وحدة

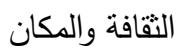
الثقافة : كل ما ينتجه الإنسان وتتمنل وحدات الثقافة فى

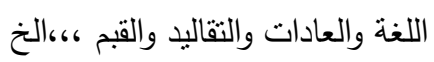
كما تعد مشاركة أفراد المجتمع فى ثقافة ما شرطآ اساسيآ

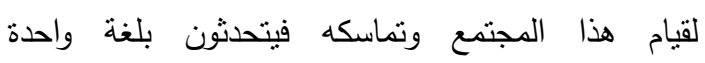
ويخضعون لنظام حكم معين ويؤمنون باهداف محددة بذلك تجمعهم وحدة النقافة ويتماسك المجنمع ويتكامل شخصية الفرد ليست نااحية جسمية أو عقلية أو نفسية أو اجتماعية فحسب ، وأنما تتكون نتيجة تفاعل لكل هذه النه النواحى المتداخلة ، بين بعضها البعض بصفة مستمرة

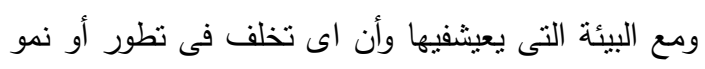

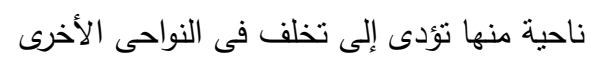




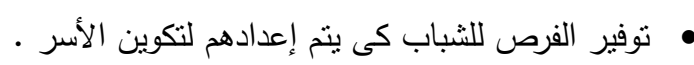

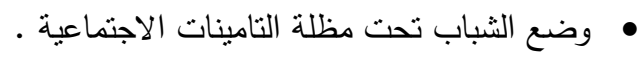

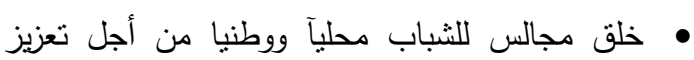

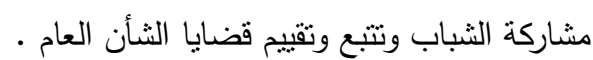
• الرقى بالعمل الجمعى مع الثباب فى المناطق النائية والوسط القروى والمناطق المهشية ودعم قدرات الموارد

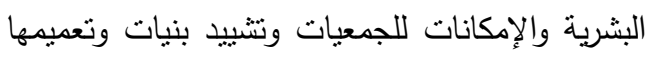
من أجل مواجهة الطلب التربوى والاجتماعى والتتموى اللشباب.

• تتظيم ندوات ومحاضرات نثقيفية وسياسية داخل

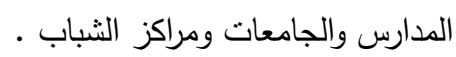
• عدم المغالاة للثباب فى أماله إلى الحد الذئى يتجاوز

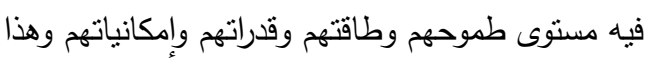

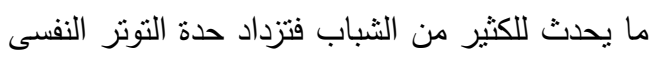
ويقع فريسة سهلة للإدمان والأنحراف والدخول في دائرة التطرف ، ودائرة العنف والاخول فى دائرة الجريمة

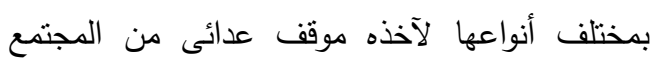
وسخطه عليه حيث أنه لم يوفر له الآمن والأمان من الجتئ

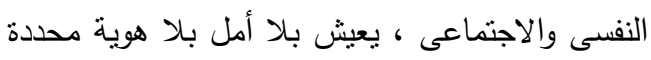

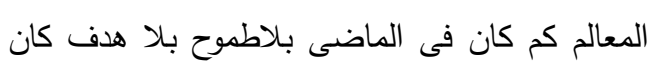

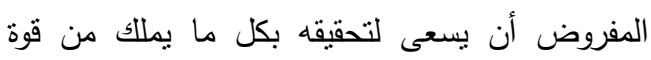

$$
\text { وإرادة ولكنها للاسف مسلوبة . ل }
$$

مراعاة هؤلاء الثباب فكريا من خلال تتمية عادات القراءة وأحترام الرأى الآخر وكذللك تتمية قدرات التفكير

$$
\text { وأساليب حل المواقف والمشكلات الصعبة . ل }
$$

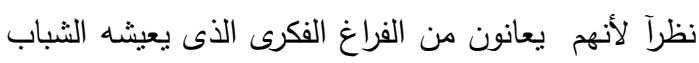
السيناوى من الجنسين نتيجة للظروف الإقتصادية

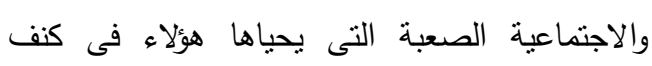
الأسرة البدوية السيناوية التى تعانى فى تدبير أمورها

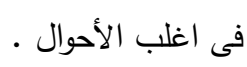

ان الأكتئاب حالة مرضية تتفاوت فى حدتها وبساطتها

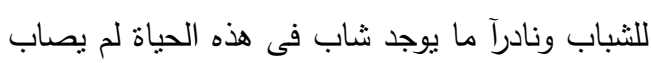
بحالة أكتئاب

فلابد من نوفير المناخ المنوازن وإقرار حق الثباب فى الرئ

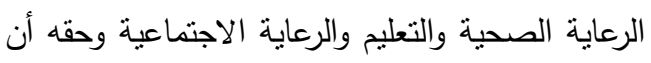

• تعزيز وتدعيم الانماط السلوكية الإيجابية التى يقوم بها

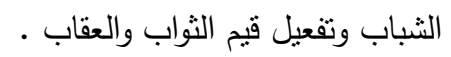
• مساعدة الثاب على ان يكون فعال ويتم ذلك بسؤاله

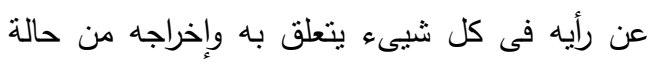
الصمت والانعزالية والإنطوائية والأهتمام برايه بـايه

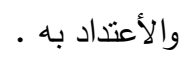

• أستخدام البرامج المسموعة والمرئية لتوضيح كيفية

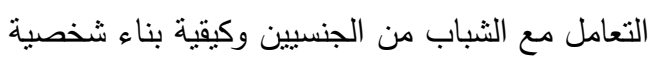

$$
\text { سوية قادرة على التعلم وكسب الخبرات . }
$$

المدرسة : هى الأداة الرسمية للتربية والتعليم قد أوجدنها

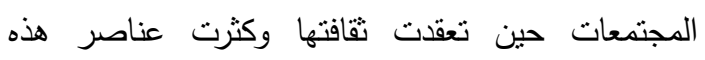
الثقافات جعل الثاب مواطن اجتماعى قادر على التفكير والعمل والانتاج فى جماعة والمشاركة فى العلاقات الاجتماعية والمساهمة فى بناء المجتمع وتقدمه.

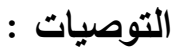

• إعداد البرامج النفسية والتزبوية لإعادة تأهيل الثباب

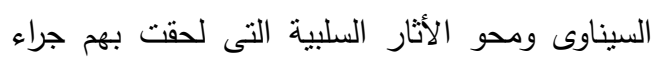

$$
\text { فترة تطهير أرض سيناء من الأرهاب الأسود . }
$$

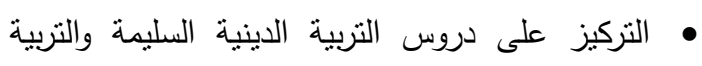

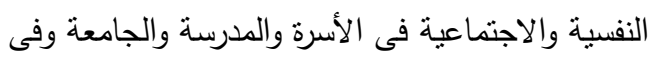

$$
\text { جميع الوسائط التربوية المختلفة . }
$$

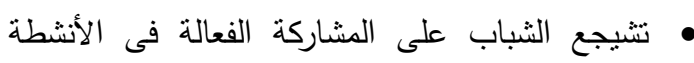
الرياضية والثقافية النى تعزز بناء الثخصية القوية

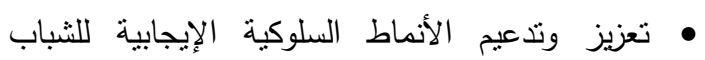

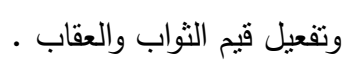
• أخذ راى الثباب فى كل شيىء يتعلق بهم وإخراجهم

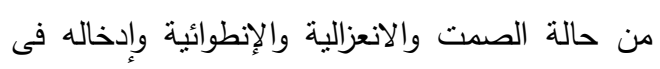

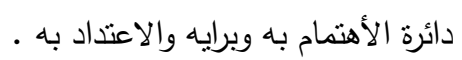

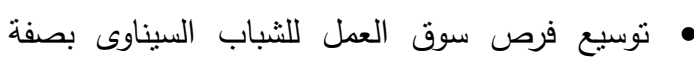

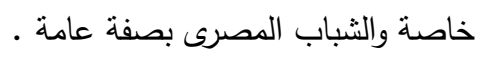
• تعزيز الجانب الصحى للشباب . • • م مارسة المواطنة .

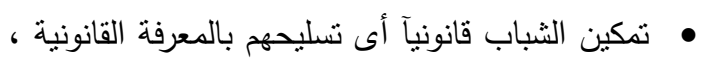
وتدريبهم على مداخل القانون ومخارجه . 
طلبة المرحلة الإعدادية ، رسالة ماجستير غير منشورة

، جامعة بغداد ، كلية التربية ابن رشد .

*- الساعاتى ، سامية ، (2003 ) : الثباب العربى

والتغيرات الاجتماعية ، الدار المصرية اللبنانية .

* الثعراوى ، محمد منولى : خواطر إيمانية

*- العبيدي ، ناظم هاشم ، ( 1995) : العدوان الثلاثيني

على العراق وأثثه في بعض الجون ، الجوانب النفسية

والاجتماعية المرتبطة بشخصية الطالب الجامعي

وانتمائه الوطني ، مجلة الأستاذ ، العدد السادس .

*- العظماوي ، إبراهيم كاظم ، (1988) : معالم

سكيولوجية الطفولة والفتوة والثباب ، ط1 دار الثؤون

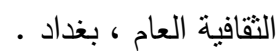

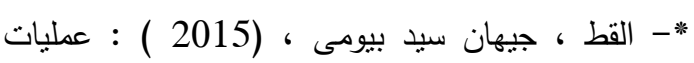

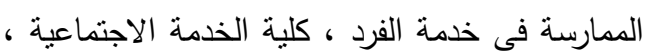

جامعة حلوان ، مكتبة دار السحاب .

*- القذافى ، رمضان محمد ، (1998 ) : الصحة مكانه

النفسية والتوافق ، الإسكندرية ، المكتب الجامعى

$$
\text { الحديث. }
$$

*- القريشى ، غنى ناصر حسين ، (2012 ) : المفهوم

العلمى للضبط الاجتماعى ، كلية الاداب ، شبكة

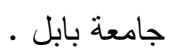

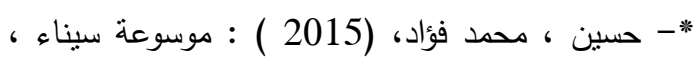

القاهرة ، الهيئة المصرية للكتاب .

* - جابر، نصر الدين ، (1998) : العكاسات أسلوب

التقبل/الرفض الوالدي على تكيف الأبناء في فترة

المراهقة، جامعة بسكرة ، مجلة جامعة قسنطينة مجلة

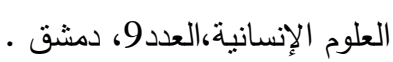

*- جبر ، محمد ، (2015 ) : تعريف القلق وأعراض

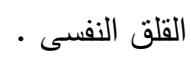

* - دعبس ، محمد إبراهيم يسرى ، (2006 ) : التصحر النفسي والوقاية منه دراسات وبحوث في الأنثروبولوجيا السيكولوجية ، البيطاش سنتر للنشر والتوزيع

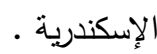

يعيش فى جو يسوده الإلفة والمحبة والوئام وتوفير حاجاته الضرورية الفسيولوجية والإهتمام بإشباع حاجاته النفسية والثقافية .

- أبو جادو، صالح محمد علي، (1998) : سيكولوجية

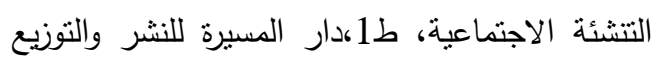

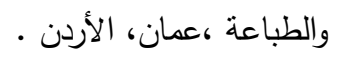
*- أبو النيل ، محمود السيد (1984 ) : علم النفس النس الاجتماعى ، بحوث عربية وعالمية ، الجزء الأول ، الجهاز المركزى للكتب الجامعية ، القاهرة . *- العتيق ، أحمد مصطفى ، (1996 ) : التباين فى بعض المتغيرات النفسية لدى عبنات من مساكن أنماط مختلفة من مساكن البيئة الحضرية فى مصر ، دراسة فى علم النفس البيئى ، معهد الدراسات والبحوث البيئية ، جامعة عين شمس • *- الحلفي ، ماجد رحيمه ، ( 2010) : القبول / الرفض جم الوالدي وعلاقته بشخصية أبنائهم التشلطية وسلوكهم اللا اجتماعي،أطروحة دكتوراه غير منشورة،الجامعة المستتصرية،كلية التربية،قسم الإرشاد النفسي والتوجيه

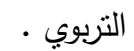
*- الأنصاري ، بدر محمد ، (1995) : دراسة عامليه للحالات الانفعالية للثباب الجامعي في الكويت، المؤتمر الدولي الثاني عن الصحة الانفعالية في الئي دولة الكويت ،مكتب الإنماء الاجتماعي المنعقد في الفترة من 1-4من أبريل 1995 ـ 1995 *- الأهوانى ، هانى حسين ، (2002 ) : الصحة النفسية

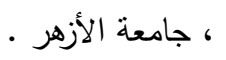
*- الثيباني ، عمر تومي ( 1987) : الأسس النفسية والاجتماعية لرعاية الثباب ، الدار العربية للكتاب ، لوبياب ل

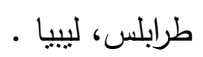
*- الدوري، وصال محمد جابر ،(1998) : الشخصية لمربل، السيكوباثية وعلاقتها بأساليب المعاملة الوالدية لدى 


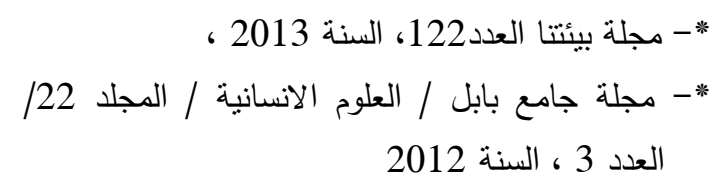

fatwa :islam web .net

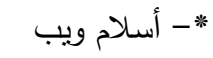

$$
\text { المراجع الأجنبية : }
$$

- Adams, H, (1993). Aggression and violence, comprehensive Hand book of psychopathology, New York : Edwin I, mega gee

- Black, (1979). Psychology and personality :The Dimensionality of self -Report and Behavior Rating Data in Abnormal offend ,The British Journal of social and clinical psychology , Vol,18,part I February pp,111-119.

- Hare, R. D. (1970): Psychopath Theory and Research, New York : Wiley and sons.

- Kelly, T. I. (1973). The Selection of upper and lower group for the validation of test item, consistence of the A dull personality, journal of Educational psychology, No, 21.

- Rhone, R. (1986). Theory of Accept and refuse parental for their children New York

- Salmons, Sandra (1997). Depression: Questions you have - answers you need, People's Medical Society.

- Thomas, Z, (1976). Krakow ski, a system the org of Human Needs and society chins, Mole Bay press, London.

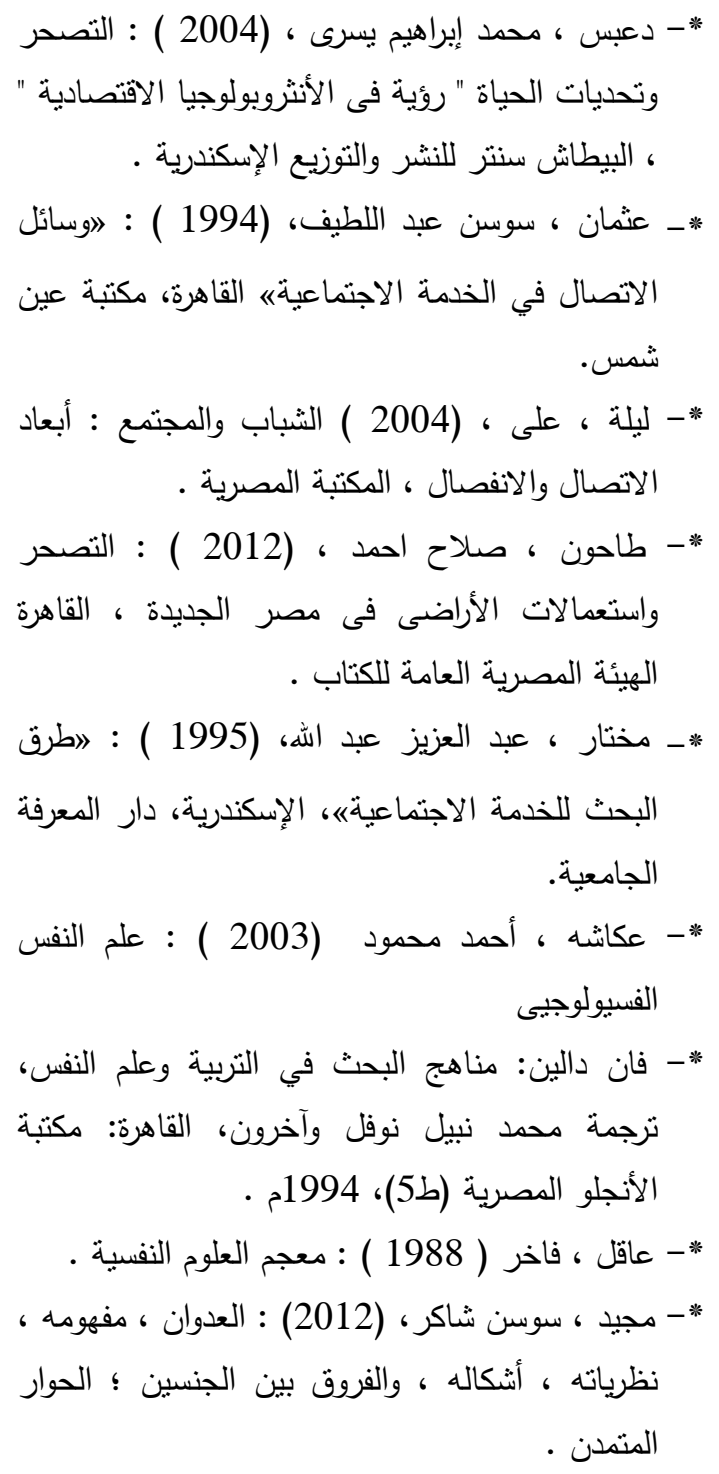




\title{
PSYCHOLOGICAL AND SOCIAL DESERTIFICATION AMONG SINAI YOUTH IN NORTH SINAI GOVERNORATE
}

\author{
A. S. Ibrahim and H. G. Shaban \\ (1) Head of the Rural Society Division, Faculty of Agriculture, Al Zahra University \\ (2) Researcher, Socio-economic Studies department, Social Studies Division, Desert Research \\ Center
}

\begin{abstract}
Sinai youth are living in a state of psychological and social desertification varies from minor to simple and severe. Sinai youth have become living in a state of social depression in the light of the deteriorated social circumstances and consequences at all levels within the Sinai society on all the forms and levels of demeaning the simplest rights and dignity of mankind which befall the youth with a state of resentment, frustration and failure.

In the light of the main questions and within the relevant objectives and the research techniques that aim to achieve such objectives, the research concluded the following results:

- There was a reverse significant correlation between the satisfaction with the society and the suffering from anxiety and depression meaning that satisfaction means to satisfy the basic needs, which is an indication of happiness and includes various aspects in the individual's life i.e. the physical, psychological, social, spiritual and moral health at the same time it means to embrace life such society at any how and to get content with what Almighty Allah has given to him, to accept the self and the others through forgiveness, hence will get less stressed and psychological diseases free, on the other hand, discontent renders him anxious, stressful and afraid of what the future holds, thus his time being renders frustrated and jobless with unknown future.
\end{abstract}

- Results showed that some aspects were satisfied by some respondents, whereas some were dissatisfied by others, results indicated that most of the respondents were of the average level of satisfaction, which entails the officials in charge of the Sinai society to meet their needs and complete the services to step up their level of psychological satisfaction and stability within the society.

- Results showed also that more than two thirds of the respondents $(38.0 \%)$ are the civil servants- the poor of the middle class- though they have certain income, meanwhile there is a state of inflation (high prices) which devour all the income, so not only the Sinai youth who are suffering from the inflation, but also the whole Egyptian society in general, around one quarter of the respondents (24.7\%) and less than one fifth for the respondents (20.0\%)are unemployed, so they have no source of income and they get subjected to the psychological and social incompatibility besides the bulk of unemployment is represented by the youth and the deteriorated economic, social and psychological situations, thus the youth will render from man force and massive energy that help support the economic stance to become an economic burden on the society.

- Results showed that faith and other qualities such as sincerity, honesty and fairness are intrinsic and inherent characteristics for the Sinai youth.

- The research resolved that some daily life pressures were the major reasons that led to the psychological and social desertification within the family. at work and in the daily life milieu.

Key words: Psychological desertification- social desertification -Youth-Sinai. 
Psychological and social desertification among sinai youth in north 